\section{The Ottoman Period Fountains in Molova (Molyvos / Mithymna) In Lesvos}

Ammar İbrahimgil, ORCID: 000-0002-6801-7672

\section{Keywords}

Lesvos, Molyvos, Ottoman era, fountain, typology, cultural heritage

\section{Abstract}

Molova (Molyvos) is located on the island of Mytilene in the Aegean Sea. The Greek name of Lesbos Island, the third largest island in the Aegean Sea, is Lesvos. The most historical cities of the island are Lesvos (Mytilini), Molova (Molyvos) and Sigri. Molova, located in the north of the island, is one of the most harmonious and beautiful cities of all Aegean islands with its unique architecture preserved to date. The island joined the Ottoman administration in 1462 and came out of Ottoman rule in 1912. Only 75 of the monuments built on the island during the Ottoman period have survived to the present day. In this paper, ten fountains that survived in the town of Molova (Molivos) on the island were discussed. Six of these fountains are detached, while the other four are examples of fountains adjacent to the wall. Among the seven fountains with inscriptions, Hac1 İsmail Ağa Fountain (H.1189 / M.1775), Hac1 Ahmet Ağa Fountain (R.1180 / M.1766) and Hac1 Mustafa Fountain (R.1300 / M.1884) construction dates and founders are known, and only the construction dates are known since the inscriptions of the other three fountains were damaged. In case the inscription of the three fountains has not survived to the present day. In addition, a certificate of foundation dated H.1233 / 1817 was found related to these fountains. The measurements of these ten fountains were taken, facade and plan drawings were prepared, their inscriptions were dated by reading and archive documents were reached. In the terms of the data we have obtained, the historical and architectural features of the fountains will be explained and compared with similar examples in İstanbul, Chios and Rhodes island.

\section{Article Information}

Received: 18.05 .2020

Accepted: 28.07 .2020

Available Online: 29.05 .2020

Article Classification: Research Article

Necmettin Erbakan University, Department of Architecture, Konya ibrahimgil.ammar@gmail.com 


\section{Midilli Adası Molova'da (Molivos / Mithymna) Osmanlı Dönemi Çeşmeleri}

Ammar İbrahimgil, ORCID: 000-0002-6801-7672

\section{Anahtar Sözcükler}

Midilli Adas1, Molova, Molivos, Osmanlı dönemi, çeşmeler, tipoloji, kültürel miras

Makale Bilgileri

Alındı: 18.05.2020

Kabul edildi: 28.07.2020

Erişilebilir: 29.05 .2020

Makale Kategorisi: Araştırma Makalesi
Molova (Molyvos) ve Sigri şeklinde sıralanmaktadır. Adanın kuzeyinde bulunan Molova günümüze kadar koruduğu özgün mimarisi ile bütün Ege adalarının en ahenkli, en güzel şehirlerindendir. Ada, 1462 yılında Osmanlı idaresine katılmış ve 1912 yılında Osmanlı idaresinden çıkmıştır. Osmanlı döneminde adada inşa edilen mimari eserlerden sadece 75 tanesi günümüze ulaşabilmiştir. Bu çalışmada Molova (Molivos) kasabasında ayakta kalmayı başaran on çeşme ele alınmıştır. Bu çeşmelerden altısı müstakil, diğer dört çeşme ise duvara bitişik çeşme örnekleridir. Incelediğimiz çeşmelerden yedi tanesinde inşa kitabeleri mevcut, diğer üç tanesinin ise kitabeleri yoktur. Kitabesi olan yedi çeşmeden Hacı İsmail Ağa Çeşmesi (H.1189/M.1775), Hac1 Ahmet Ağa Çeşmesi (R.1180/M.1766) ve Hac1 Mustafa Çeşmesi'nin (R.1300/M.1884) hem banileri hem de inşa tarihleri bilinmekte, diğer üç çeşmenin ise kitabeleri tahrip edildiği için sadece inşa tarihleri bilinmektedir. Üç çeşmenin kitabesi ise günümüze ulaşamamıştır. Ayrıca bu çeşmelerle ilgili H.1233 / M. 1817 tarihli bir vakfiye de tespit edilmiştir. İncelenen bu on çeşmenin ölçüleri alınarak cephe ve plan çizimleri hazırlanmış, kitabeleri okunarak tarihlendirilmiş ve arşiv belgelerine ulaşılmıştır. Araştırmada elde edilen veriler 1şı̆̆ında, çeşmelerin tarihi ve mimari özellikleri İstanbul, Sakız ve Rodos adasındaki benzer örnekleri ile karşılaştırmalı örneklerle tarihlendirilmesi yapılmıştır.
Necmettin Erbakan Üniversitesi, Mimarlık Bölümü, Konya ibrahimgil.ammar@gmail.com 


\section{GİRİS (INTRODUCTION)}

Osmanlılar tarafindan Saruhan adalar grubu içinde tanımlanan Midilli Adası, Fatih Sultan Mehmet döneminde Zilhicce 866 (Eylül 1462) yılında Osmanlı egemenliği altına girmiştir. Günümüzde ise Doğu Sporatlar ada grubu içinde Lesvos Adası olarak isimlendirilmektedir. Ayvalık'ın tam karşısında yer alan bu adanın en büyük şehri ve idari merkezi Midilli (Mytilini)'dir. Diğer tarihi şehirleri ise kuzeydeki Molova (Molivos / Mithymna) ve batıdaki Sigri'dir. Adadaki ilk Türk yerleşimi fethin hemen ardından gerçekleşmeye başlamış ve bu yerleştirilenler arasında Yenice Vardar'dan Barbaros Hayrettin Paşa'nın babası Yakup Bey de vardır (Keil, 2005, s. 11). Ada Cenevizliler'den fethedildikten sonra birkaç defa Haçlı donanmaları tarafindan kuşatılmış ve yağmalanmıştır (Nicolle \& Hook, 2013, s. 8). 1501'deki Hıristiyan donanması kuşatmasından sonra II. Beyazid'ın Midilli Kalesi’ni güçlendirdiği 914 (1508) tarihli Arapça iki kitabe günümüze ulaşabilmiştir. Aynı dönemde Molova kalesinde de savunma amaçlı önemli tamirat ve değişiklikler yapılmıştır (Kriara, 2013, s. 61). Türklerin fethiyle ada, 1204 Latin İstilâsı sonrası kaybettiği önemini tekrar kazanmış ve hızla gelişmiştir (Kontos, 1962)

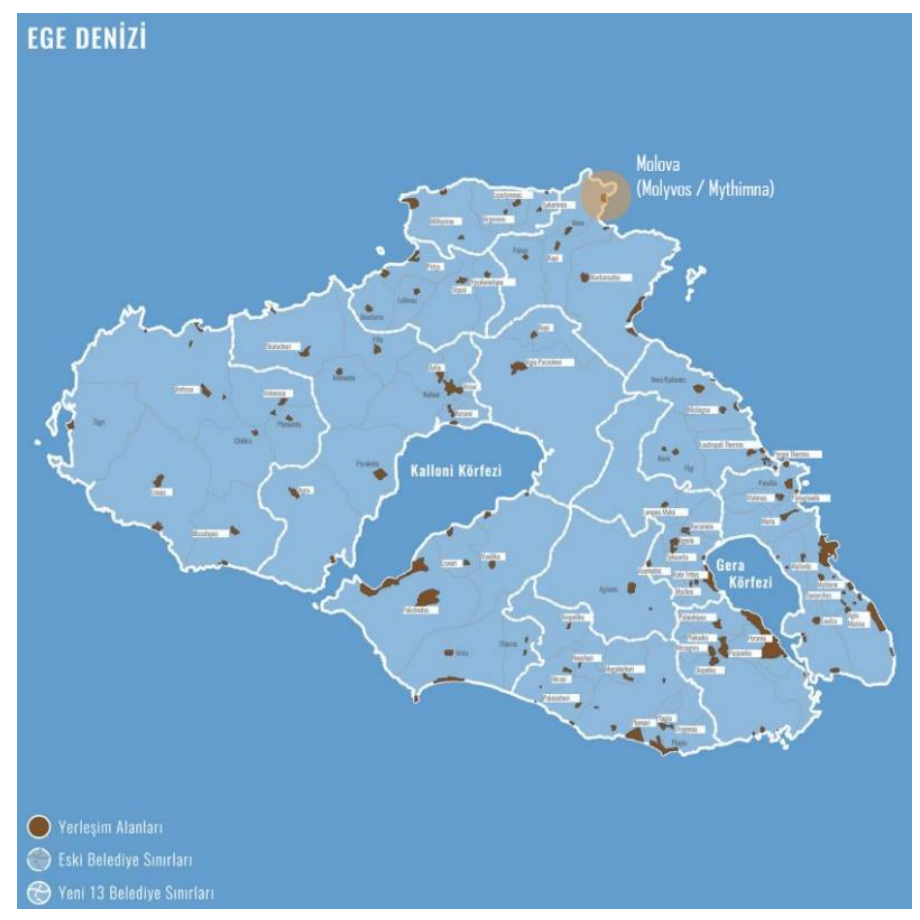

Şekil 1. Midilli Adası, yerleşim yerlerini gösteren harita (Settlements in the Lesvos Island) (Olgun, Altıner, Çılgı̀, \& Turgut, 2018, s. 677) 

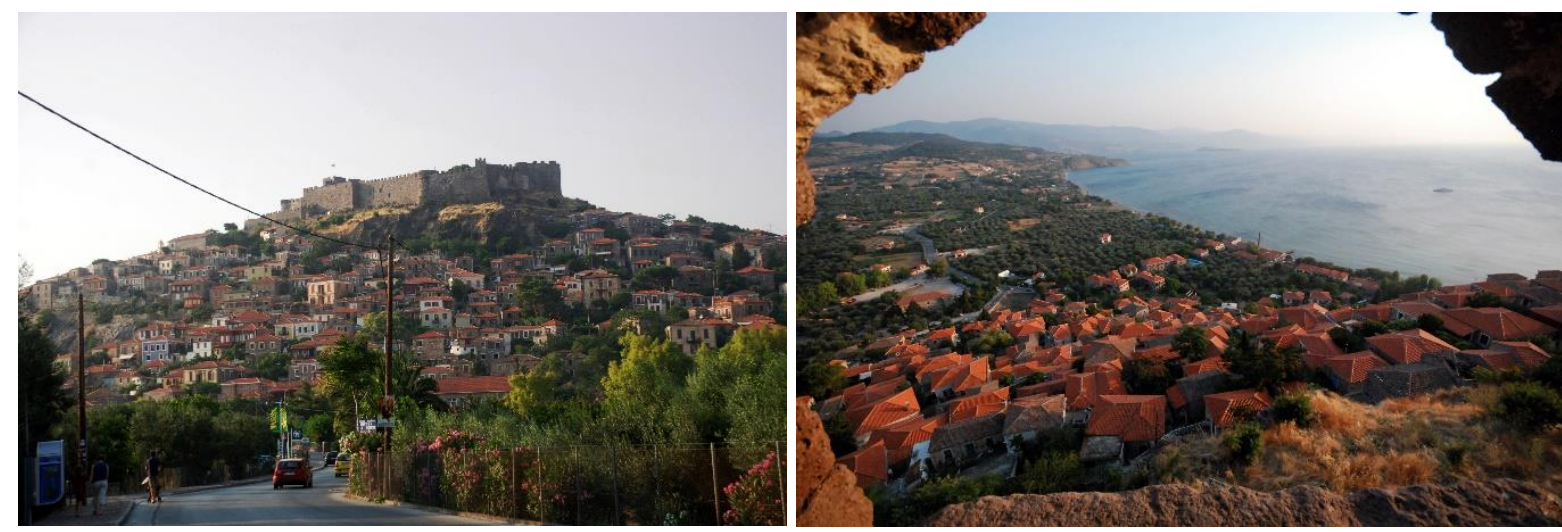

Resim 1. Molova (Molivos / Mithymna) şehrinin karşıdan ve kaleden görünümü (Frontal view and from castle view of Molivos city)

16. yüzyıldaki eyalet kayıtlarına göre Cezayir-i Bahri Sefîd Eyaleti'nin çekirdeğini teşkil eden Gelibolu, Midilli ve Rodos'tur. 1849 kayıtlarına göre Midilli Sancağı, Pilmar ve Molova kazalarından oluşmaktaydı 1864 Vilayet Nizamnamesine göre ise Midilli adası vilayet olmuştur (Ünal, 2002). Müslümanlar, adada daha çok Ayvalık'ın karşısındaki liman şehri Midilli'ye yerleşmiştir. Adadaki diğer yerleşimler topografik yapısından dolayı daha çok zeytinlik ve diğer tarım işleri için kullanılmıştır (Rebaudo, 2016, s. 651). Cenevizlilerden fethedildikten sonra adada Midilli ve Molivos'ta iki kadılık merkezi kurulmuştur. Adanın Midilli kasabasında yoğun Müslüman nüfusa karşl1ık, tepe üstünde bir kale ve yamaca oturan bir yerleşim düzenine sahip Molivos kasabasında 1521'de sadece 6 Müslüman hane bulunmaktaydı. 2300-2400 nüfuslu Molivos kasabas1 40 kişilik bir garnizonla korunmaktaydı (Karydēs \& Kiel, 2000). Şehir, II: Cihan Harbi ve Yunan İç Savaşı'ndan çok etkilenmiş, nüfusunun bir bölümü Yugoslavya'ya göç etmek zorunda kalmıştır (Faidon, 2010).

\section{MOLOVA'DA OSMANLI DÖNEMİ (OTTOMAN ERA IN MOLYVOS)}

Karydes ve Kiel'in Cezayir-i Bahri Sefîd Eyaleti salnamelerinden bilgilere yer verdikleri çalışmalarında 1462'de fethedilen şehirde ilk yüzyılda askerler hariç ancak 22 Müslüman hane olduğu belirtilmiştir. Fetihten 250 yll kadar sonra 1700'lerin başında ise Müslüman nüfus gayrimüslim nüfusun beşte biri kadardır. 19. yüzyılın son çeyreğinde ise Müslüman nüfus gayrimüslim nüfusu geçmiştir (Karydēs \& Kiel, 2000). Bu dönemde ada genelinin nüfusu beş kat artmış ancak, Müslüman nüfus oranı dramatik bir azalma göstermiştir (Keil, 2005, s. 12). M. Keil’in çalışmasında ele alınan salnamedeki nüfus bilgileri aşağıdaki gibi bir tabloda gösterilmiştir. $\mathrm{Bu}$ tablodan da anlaşılacağı üzere 1700'lerde 500 gayrimüslim haneye karşlık, 136 müslüman hanesi bulunurken 19. yüzyllın son çeyreğine girerken Müslüman nüfus gayrimüslim nüfusu geçmiştir. Kale dışındaki İslâm eserlerinin en erken tarihlileri de 1700'lü yıllara tarihlenmektedir. Burada ilginç olan özellikle 1821 Yunan İsyanı ile adalardan, Anadolu tarafına yoğun göç hareketinin başladığ1 bir yüzyılda bu bölge, adanın genelindeki nüfus hareketine zıt bir seyir göstermesidir. Ada genel olarak hiçbir zaman bu isyanlara katılmadığı gibi destek de vermemiştir. Hatta II. Balkan Harbi sonrası Cemal Paşa'nın memleketi olan adanın Osmanlı'ya devri konuşulurken I. Dünya Savaşı'nın patlak vermesinden dolayı bu görüşmeler sonuçsuz kalmıştır. Adadaki bu farklı siyasi iklim 
Osmanlı'nın son dönem mimari eserlerinin tarzına da yansımıştır. Namık Kemal'in idareci olarak parladığı bu adadaki özgün siyasi duruş Jön Türk hareketinden bağımsız düşünülmemelidir.

Adanın ve de özellikle Mithymna (Molova) bölgesinin bu özgün siyasi duruşu Osmanlı sonrası Yunanistan iç siyasetinde de devam etmiştir. Hatta günümüzde Yunanistan'da en az karşılık siyasi fikirler, özellikle adanın bu bölgesinde büyük destek bulmaktadır. Ayrıca bu yerleşim sakinlerinin büyük bir bölümünün Yunanistan iç savaşında eski Yugoslaya'ya sürüldüğü de unutulmamalıdır. Sahip olduğu doğal limanı, verimli toprağı dolayısıyla Antik dönemden beri Midilli şehrinden sonra adanın en önemli ikinci merkezi olan bu yerleşim, Osmanlı sonrası adanın diğer yerleşimlerine göre çok geri kalmıştır. Şimdilerde sadece özgün mimarisiyle turistlerin ilgisini çeken 1000 nüfuslu (2011) bir kasaba olarak varlığını sürdürmektedir (NSSG, 2009, s. 280).

Molivos'ta 1700'lerden itibaren hızlı bir şekilde artan Müslüman nüfus için büyük bir cami yapılmıştır. Bunların dışında Hasan Reis Camii, Fatima Hatun Mescidi (H. 1167/M. 1754) ile bir Halvetî ve bir Kadirî tekkesi bulunmaktaydı (Keil, 2005, s. 12). Molivos’ta Osmanlı döneminde yapılan eserlerden günümüze, minaresi kaidesine kadar yıkılmış bir cami ile bir idari bina, büyük bir kısmı yıkılmış su kemeri ve farklı yerlerde karşımıza çıkan suyolları ulaşabilmiştir. Bunların yanında araştırma konusu olan on adet çeşme de Osmanlı döneminin tanıkları olarak hâlâ ayaktadır. Bu yapılar ile ilgili en önemli kaynak "VGMA, Defter No: 987, Sahife: 177-179, Sıra No:56/1; Hicri 1 Muharrem 1233 / Miladi 11 Kasım 1817” tarihli Hacı Mustafa Ağa'nın torunu Hacı Numan Ağa vakfiyesidir. İncelenen çeşmelerden birinin kitabesinde de bani ismi olarak Hacı Mustafa Ağa’nın ismi geçmektedir.

Tablo 1: $\quad$ Yüzyıllara göre Molova'da değişen nüfus oranları (Changing population rates in Molivos by centuries)

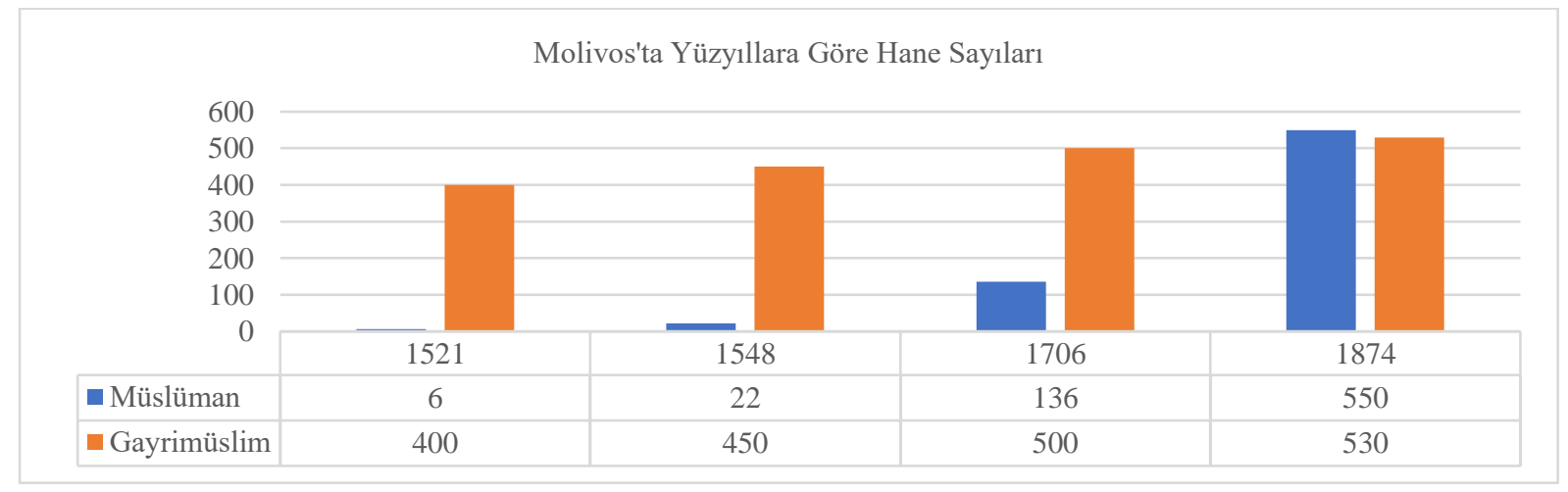

Yukarıda sözü edilen belge ve çalışmaların dışında Molivos’taki Osmanlı eserleri özelinde çeşmelerle ilgili yapılmıs kapsamlı bir çalışma yoktur. Günümüzdeki toplam nüfusu 1000 kadar olan bu küçük yerleşim yeri ile ilgili daha çok şehrin tepesinde yer alan kale ile ilgili araştırmalar yapılmıştır. Bu araştırma çalışmasında ise adanın bu küçük kasabasında neredeyse her köşe başında yapılan çeşmelerin ölçüleri alınarak cephe ve plan çizimleri hazırlanmış, kitabeleri okunarak tarihlendirilmiştir. İncelenen vakıfname belgelerinden de çeşmelerin tarihi ve mimari özellikleri anlatılmıştır. 


\section{Amaç ve Kapsam (Aim and Scope)}

Kültürümüzde en önemli hayratların başında gelen çeşmeler, kültürümüzün suya verdiği değeri göstermektedir. Türkler de "Temizlik imandandır" düsturuyla kurduğu şehirlerde her köşe başını irili ufaklı çeşmelerle donatmış ve genel olarak bunun adına da hayrat demiştir ve su içenlerden tek beklentisi banilere bir Fatiha olmuştur (Önge, 1984). Bu anlamda kültürümüzdeki çeşmeler, kent mekânında ahiret inancını kuvvetlendiren bir imge olarak var olmuştur. İslâm sanatında çeşme mimarisi bahçe süsü olarak kullanılan selsebiller, abdest alma mahali olarak kullanılan şadırvanlar, suyun dışında başka içecekelrin de ikram edildiği sebilhaneler ile mahallelerin su ihtiyacını karşılayan çeşmeler şeklinde farklı mimari çeşitliliğe sahiptir (Eyice, 1993, s. 277). Bunların içinde su ihtiyacını karşılayan çeşmelerinin fiziki yapısı da dönemin mimari üslup, estetik zevk, teknoloji ve şehrin kültürel ve ekonomik gelişiminin kronolojik göstergesi olarak da kabul edilebilir. Bu çalışmanın yapılmasındaki amaç da Ege'de önemli bir adanın küçük bir kasabasındaki kent tarihinin sessiz tanıkları olan bu yapıları belgelemek ve mimari analizini yaparak mimarlık ve farklı disiplinlerden araştırmacılara kaynak oluşturmaktır. İnceleme kapsamındaki on çeşmenin yazılı kaynaklardan belgelemesi yapılmış, konum ve mimari biçimlenme yönünden incelenmiştir. Ayrıca değerlendirme kısmında yakın coğrafyalarda benzer örneklere yer verilmiştir.

\section{Yöntem (Method)}

Konuyla ilgili çok fazla kaynak olmadığından çeşmeler ile ilgili farklı araştırmalar incelenmiştir. Y. Önge'nin (1997) Anadolu Beylikler Döneminin Çeşme, Sebil ve Şadırvanları; Semavi Eyice'nin (1993) İslâm Ansiklopedisi'nde yayınlanan Çeşme maddesi; Ayla Ödekan'ın (1992) Kentiçi Çeşme Tasarımında Tipolojik Çözümleme ve Ayhan Aytöre'nin (1959) Türklerde Su Mimarisi çalışmaları esas alınarak bir sınıflandırma yapılmıştır (Önge, 1997), (Eyice, 1993), (Ödekan, 1992), (Aytöre, 1959). İncelenen çeşmelerin hepsi su hazneli olup, yapılı çevrenin içinde serpilmiştir. Molova'daki çeşmeler, konumuna göre, fizikî biçimlenişine ve kemer türüne göre sinıflandırılmış tablosu aşağıdaki gibidir:

Tablo 2: $\quad$ Konum, fizikî biçimleniş ve kemer türüne göre çeşme tipolojisi (Fountain typology by location, physical formation and arch type)

\begin{tabular}{|c|c|c|c|c|c|}
\hline \multicolumn{2}{|c|}{ A. Konumuna Göre } & \multicolumn{2}{|c|}{ B. Fizikî Biçimleniş } & \multirow{2}{*}{\multicolumn{2}{|c|}{$\begin{array}{l}\text { C. Kemer Tipi } \\
\text { 1. Penci Kemer }\end{array}$}} \\
\hline \multirow{2}{*}{$\begin{array}{l}\text { 1. Toprak } \\
\text { Altı }\end{array}$} & a. Üstü avlu & \multirow{2}{*}{$\begin{array}{l}\text { 1. Cephe } \\
\text { Sayıs1 }\end{array}$} & a. Tek Cepheli & & \\
\hline & b. Üstü bina & & b. Çok Cepheli & \multicolumn{2}{|c|}{ 2. Yarım Daire Kemer } \\
\hline \multirow{2}{*}{$\begin{array}{l}\text { 2. Toprak } \\
\text { üstü }\end{array}$} & a. Duvara bitişik & \multirow{2}{*}{ 2. Plan Şekli } & a. Çokgen & \multirow{2}{*}{$\begin{array}{l}\text { 3. Dilimli } \\
\text { Kemer }\end{array}$} & a. Çift Dilimli Kemer \\
\hline & b. Meydan & & b. Amorf & & b. Üç Dilimli Kemer \\
\hline & & \multirow{2}{*}{$\begin{array}{l}\text { 3. Çeşme } \\
\text { yüzü }\end{array}$} & a. Duvardan taşkın & \multicolumn{2}{|c|}{ 4. Üçgen Aynalık } \\
\hline & & & b. Duvar içinde & & \\
\hline
\end{tabular}

Araştırmaya konu olan çeşmelere, takip kolaylı̆̆ açısından kronolojik olarak I'den X'a kadar numaralandırılmıştır. Her çeşme için ayrı ayrı genel özellikleri ve biçimlenmesinden bahsedilmiştir. 
Tipolojik çözümlemesi ise sunum kolaylığı açısından en sonunda tablo şeklinde sunulmuştur. Aynı zamanda kitabesi olanlardan bani ve tarihlemesi ortaya konulmuş, kitabesi olmayanlardan ise arşiv belgelerindeki kayıtlara ve mimari biçimlenişine göre karşılaştırmalı çalışma yapılarak bir tarihleme yapılmıştır. Çeşmeler yukarıda bahsedildiği şekilde mimari yönden incelenerek bir tipolojisi oluşturulmuştur. Değerlendirme ve sonuç kısmında karşılaştırmalı çalışmayla aynı dönemde yapılan İstanbul, Sakız ve Rodos adasındaki çeşme yapılarına değinilmiştir. Molivos'taki çeşmelerin dönemdaşlarına göre benzerlikleri ve farklılıklar ortaya konulmuş ve günümüzdeki koruma sorunlarına değinilmiştir.

\section{ÇEŞMELER (FOUNTAINS)}

Yerleşim bölgelerinde yapılan çeşmelerin büyük bölümünün suyu, kaynaklardan su kanalları veya künkler vasıtasıyla getirilmiştir (Çeçen, 1999, s. 10). XIX. yüzyılda ise teknolojik gelişmeler sonucu çeşmelerde su haznesinin bulunma zorunluluğu ortadan kalkmış, çeşmeler müstakil veya yapı cephesine bütünleşik konumlandırılmaya başlanmıştır (Karaağaç, 2019, s. 37). Osmanlı dönemi su mimarisi ile ilgili çok fazla detay üretildiğinden bu detaylar için birçok terim bulunmaktadır (Denktaş, 2012, s. 874). Bunlardan bazıları aşağıdaki şekilde gösterilmiştir. Konu bütünlüğü açısından Molova'daki su isale sistemi için 17. yüzyılda yapılmış büyük su kemeri bu araştırmanın dışında tutulmuştur.

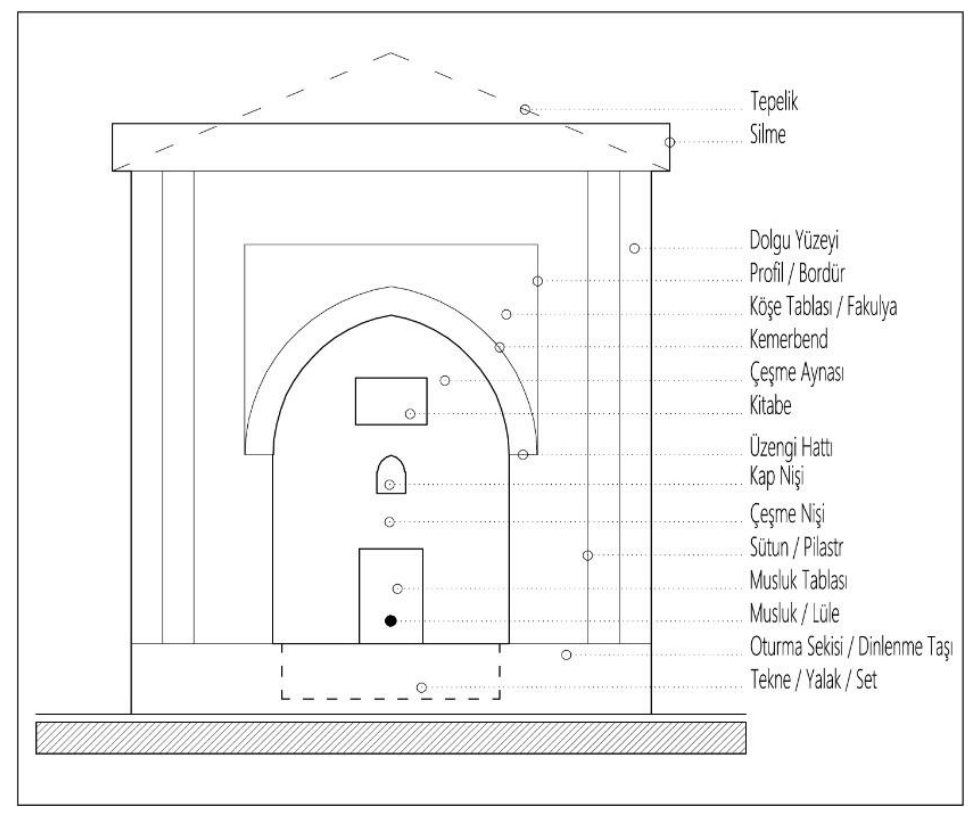

Şekil 2: Osmanlı çeşme yapısı ile ilgili terimler (Ottoman fountain terms)

\section{Çeşme I - 1710 (Fountain I)}

Çeşme kitabesine göre H. 1122 / M. 1710-11 yıllarında yapılmıştır, ancak banisi belirtilmemiştir. Buna göre Molova'da tespit edilen en eski çeşmedir. Yapıda kullanılan malzemelerden birçok defa tamir edildiği anlaşılmaktadır. Çeşmenin su haznesinin olduğu kısım, üst kotta yanındaki evin 
avlusudur. Çeşme nişi, ön yüzün solunda bulunmakta olup, ön yüzün sağ tarafinda su haznesinin girişinin bulunduğu kısım vardır. Su haznesi moloz taş örgüsüyle yapılmışken, çeşme yüzü yekpare kesme taşlardan yapılmıştır.

Çeşmenin aynalık kısmı, kenarlarda iki yekpare sütun üzerine oturtulmuş dilimli üçgen kemerle oluşturulmuştur. Ayrıca bu alınlığa bir bordür yapılmıştır. Yekpare taştan yapılmış büyük bir su teknesinin ortasında küçük bir tahliye deliği vardır. Sütunların önünde dinlenme taşı bulunmaktadır. Çeşme yapısının üstü, bütün önyüzünü dolanacak şekilde silme ile çevrelenmiştir. Ancak silmesinin tamamı günümüze ulaşamamıştır.

Çeşme nişi içerisinde alt kısımda büyük yekpare mermer bloktan yapılmış musluk tablası vardır. Tablanın orta ekseninde üst tarafta tek lülesi bulunmaktadır. Çeşme nişini oluşturan sütunların üzerinde sadece niş içine taşacak şekilde üç kademeli sütun başlıkları yapılmıştır. Çeşmenin kitabesi de çeşme nişi içerisinde bu sütun başlıklarının arasına yerleştirilmiştir. Çeşme kitabesinin üzerine aşırı şekilde kireç badana yapıldığından kabartma özelliği kaybolmuştur. İki sütun yazıdan ibaret çeşme kitabesinin günümüz Türkçe yazımı şu şekildedir: Sabibu'l-hayrat ve'l-hasenat / Rubîcun Fatiba sene 1122 (M. 1710-11). Kitabenin hemen altında ise üç adet kap nişi yapılmış, bunlardan sadece biri taslık olarak kullanılmakta diğer ikisi sağır niştir. Çeşme, özgün birçok elemanını korusa da zaman içinde yapılan bilinçsiz müdahaleler değerini kaybetmesine yol açmışır. Gövdesindeki farklı duvar örgüleri göze çarpmaktadır. Yer yer malzeme kaybı gözlenmiştir. Çeşme nişi, sütunlarla birlikte beyaz kirece boyanmıştır. Su haznesinden uzatılan metal çeşme ile günümüzde de aslî işlevini sürdürmektedir.

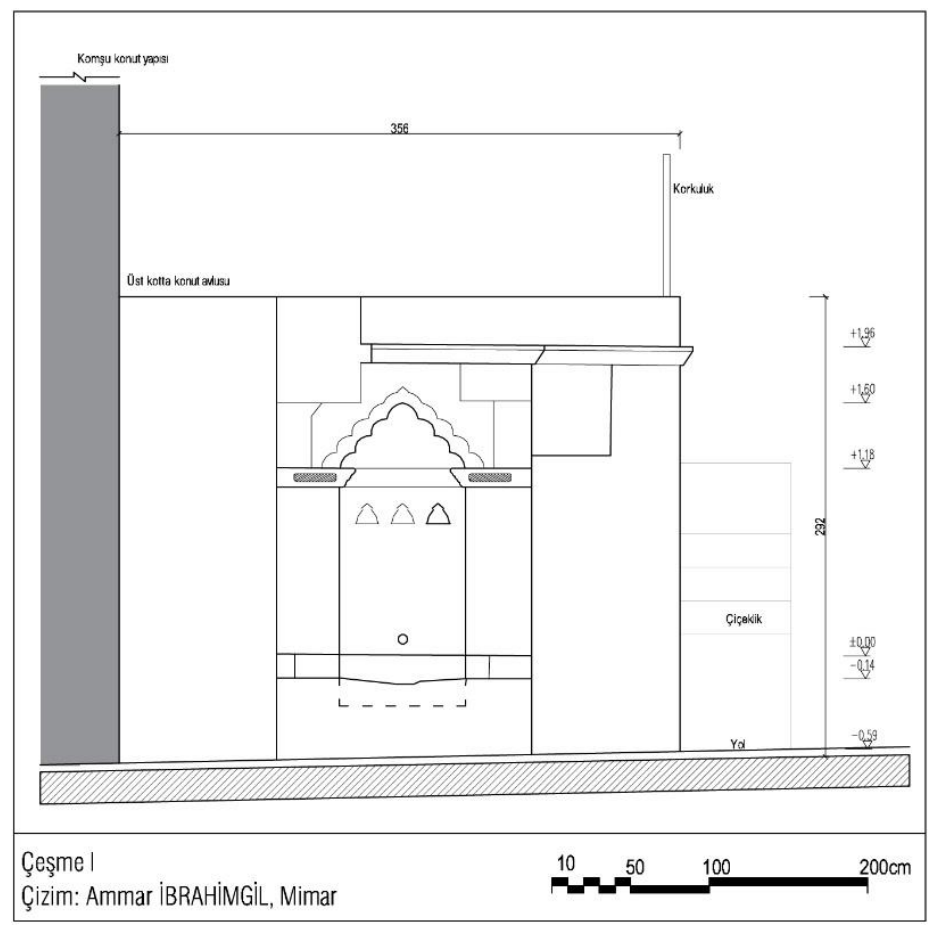

Şekil 3: Çeşme I ön cephe çizimi (Fountain I, front elevation drawing) 

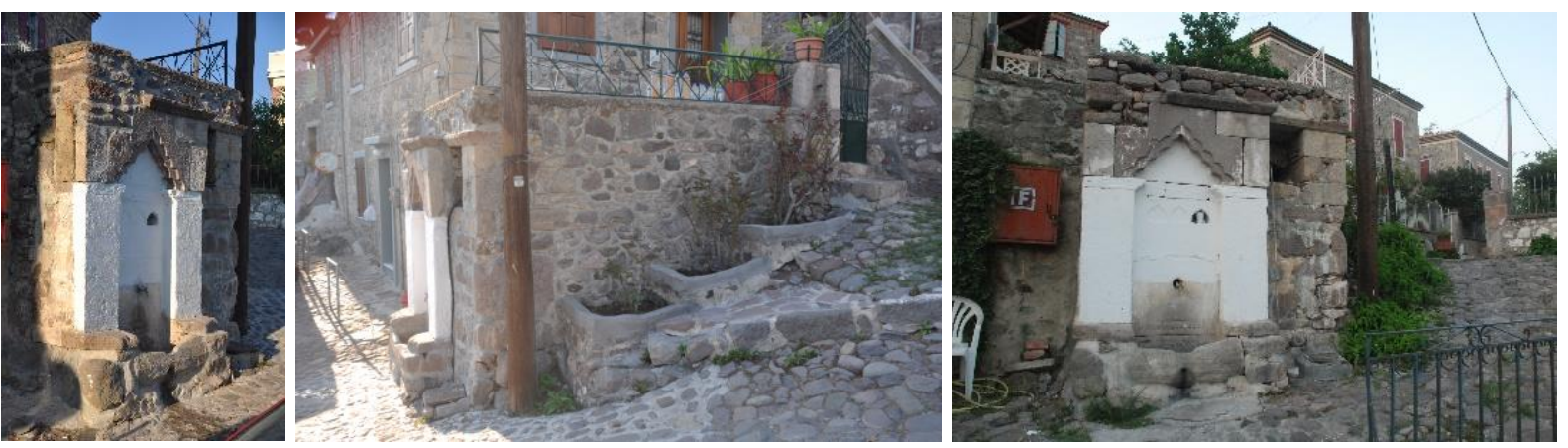

Resim 2: Çeşme I (1710-11) genel görünümü (General view of Fountain I)

\section{Çeşme II: Âlime Kadın Çeşmesi - 1736 (Fountain II: Âlime Kadın Fountain)}

Büyük bir avlunun sokağa bakan yüzünde yer alan çeşme, kitabesine göre H. 1149 / M. 1736-37 yılında Âlime Kadın tarafından yapılmıştır. Su haznesi kareye yakın dikdörtgen planlıdır. Su hazinesi moloz taş ile yapılmışken, ön yüzün ortasına yerleştirilen çeşme nişi kesme taştan yapılmıştır ve bir asaba (düz) ve iki sıra kaval (çıkıntı) pilastr ile çevrelenmiştir. Çeşme nişini oluşturan sütunların altındaki taşlar oturma sekisi şeklinde yapılmıştır. Çeşme teknesi, yere çok yakındır ve günümüzde beton atılarak set oluşturulmuştur. Çeşme aynalığ1 penci kemerlidir. Kemerin oturduğu üzengi hattında nişin içine uzatılmış karşılıklı iki yastık ile oluşturulmuştur. Çeşme aynasının üst tarafında küçük bir kitabesi bulunmaktadır. iki sütun üç satırdan oluşan mermer kitabenin günümüz Türkçe yazımı şu şekildedir: Sabibu'l-bayrat / Ve'l-basenat Âlime Kadın - Rabmetullabu Alemîn / Sene Hicri 1149 (Milâdi 1736-1737). Günümüzde suyu akmayan çeşmenin, mermerden yapılmış tek lüleli büyük bir musluk tablası vardır. Bu çeşmede ayrıca penci kemerin kilit taşına işlenmiş çarkıfelek motifi dikkat çekmektedir. Çeşme duvarlarını oluşturan yüzeylerde farklı duvar örgülerinden birçok defa tamir edildiği anlaşılmaktadır. Sol kenarı özgün hali büyük ölçüde korunmuşken, sağ tarafında meydana gelen malzeme kayıpları bilinçsiz müdahalelerle tamamlanmıştır.
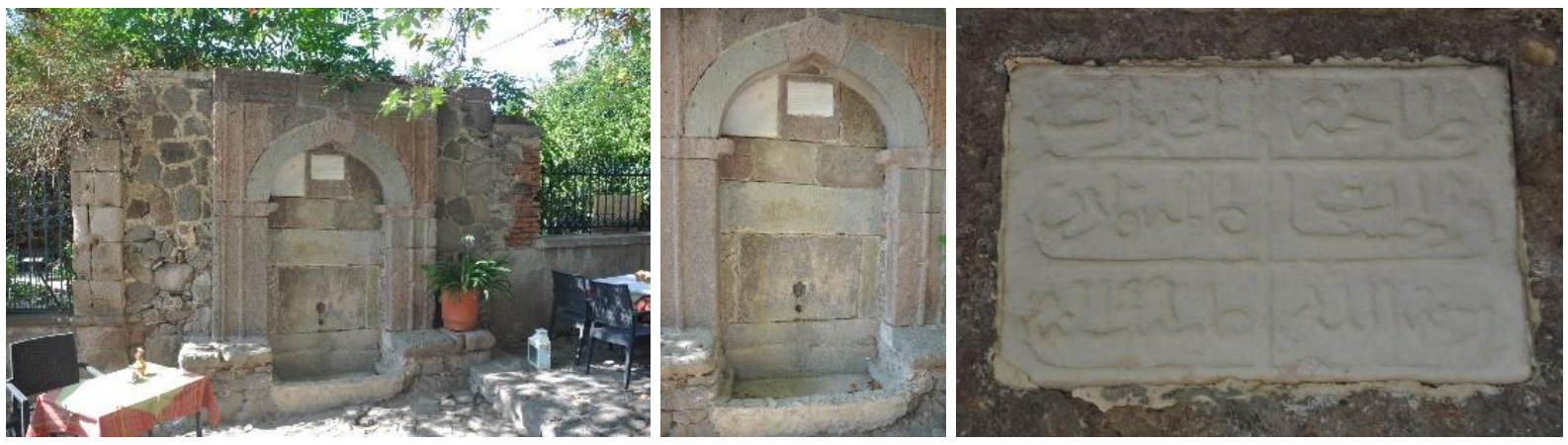

Resim 3: Çeşme II (1736-37); Âlime Kadın Çeşmesi genel görünümü (General view of Fountain II) 


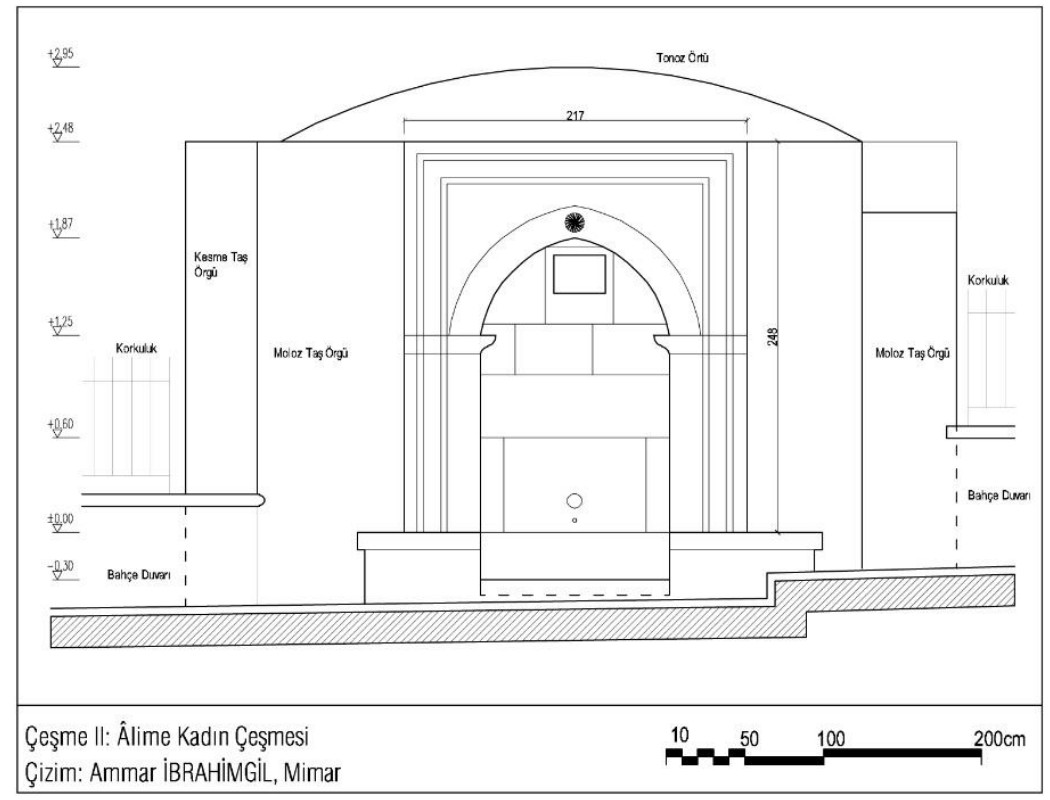

Şekil 4: Çeşme II ön cephe çizimi (Fountain II, front elevation drawing)

\section{Çeşme III: Hacı Ahmet Ağa Çeşmesi - 1766-67 (Fountain III: Hacı Ahmet Ağa Fountain)}

Çeşmenin kitabesine göre H. 1180 / M. 1766-67 yılında Hacı Ahmet Ă̆a tarafından yaptırılmıştır. Su haznesi toprak altındadır. Geniş bir istinat duvarına bitişik olan çeşme kesme taştan yapılmıştır. Çeşme nişi, yekpare sütunlar üzerine oturan yarım daire çeşme aynası vardır. Kemer köşelikleri ve sütunlar hafif dışa taşkındır. Sütun ayakları blok taşlardan yapılmış ve dinlenme sekileri üzerine oturtulmuştur. Çeşme teknesi yere yakın ve yekpare taştan yapılmıştır. Teknenin ortasında su tahliye deliği vardır. Çeşme aynalığında malzeme kayıpları ve çimento harç izleri görülmektedir. Bütün bunlara karşın kitabesi korunarak günümüze ulaşabilmiştir. Çeşme aynasının tam altında mermer levha üzerine yazılmış dört satırdan oluşan kitabenin günümüz Türkçe yazımı şu şekildedir: .(?) / Besmeleyle atşerdil(?) bu çessmeden gelen zemzemi iç / Sabibu'l-hayrat ve'l-hasenat Hacı Abmet A ̈̆ga / Sene 1180 (M. 1766-67). Kitabenin de altında kap nişi yapılmıştır. Tek lüleli musluk tablası iki sütun arasına oturtulmuş büyük bir blok taş şeklindedir. Kitabesi günümüze kadar ulaşan bu çeşmenin üst bölgesinin duvar örügüsünden basit bir tamirden geçirildiği anlaşılmaktadır. Çeşmenin silmesi zaman içinde geçirdiği bilinçsiz müdahaleler sonucu yok olmuştur. 


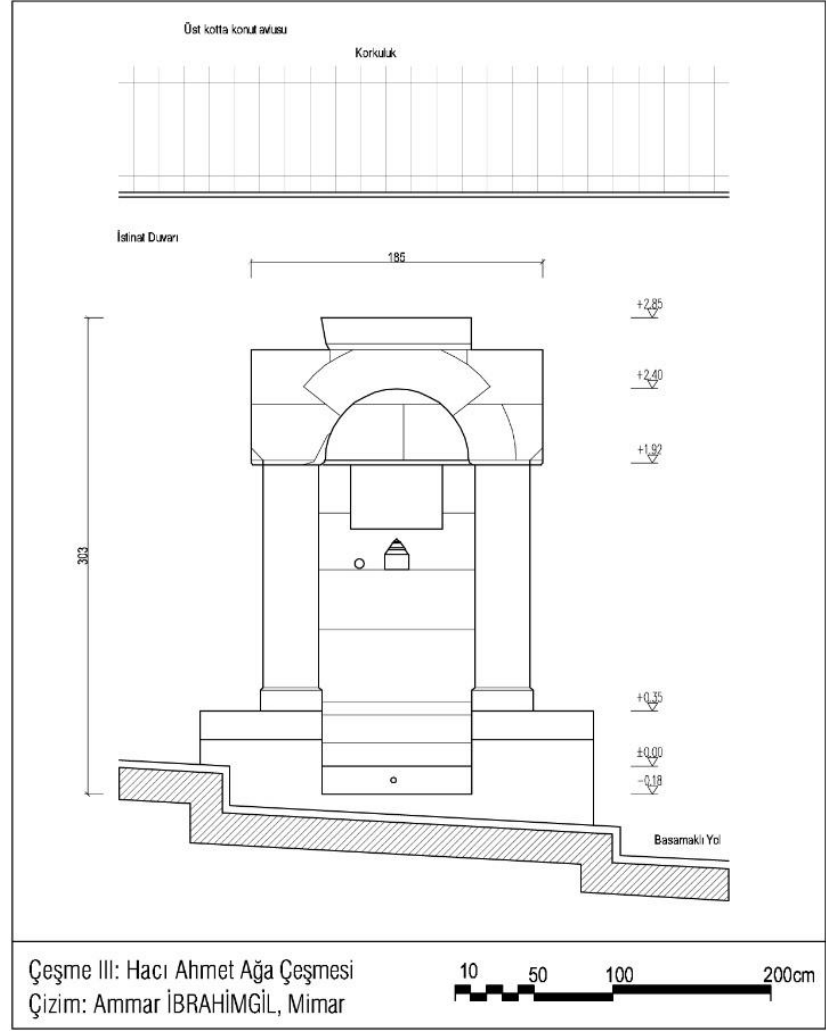

Şekil 5: Çeşme III ön cephe çizimi (Fountain III, front elevation drawing)
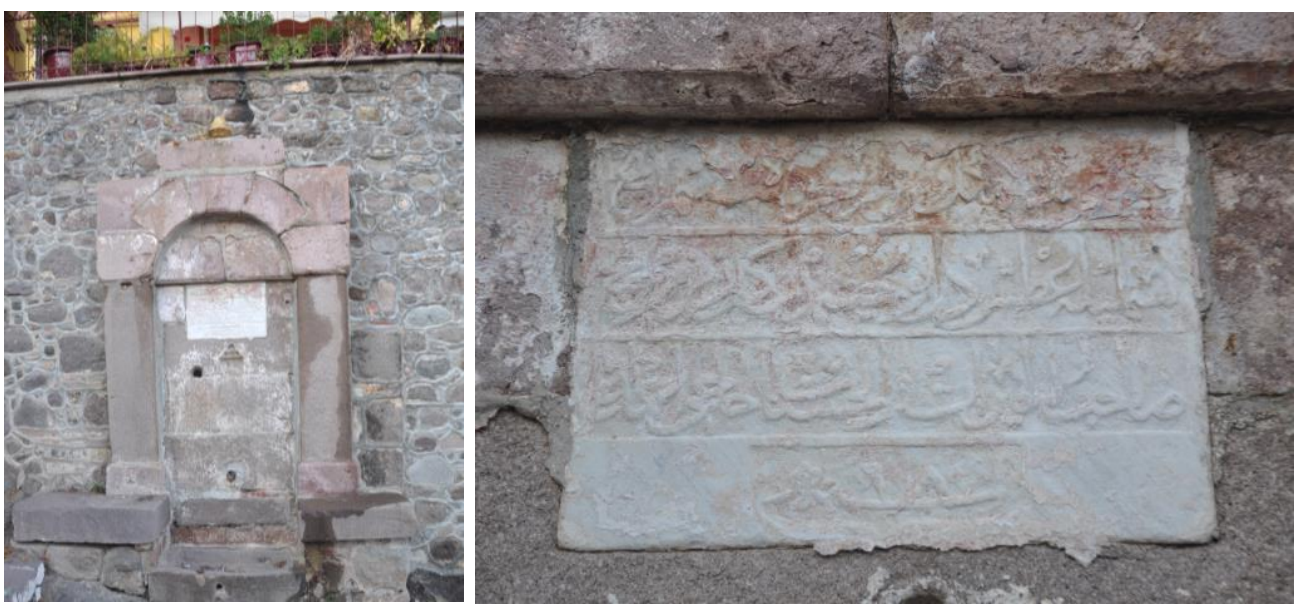

Resim 4: Çeşme III (1766-67); Hacı Ahmet Ağa Çeşmesi genel görünümü (General view of Fountain III)

\section{Çeşme IV: Hacı İsmail Ağa Çeşmesi - 1775 (Fountain IV: Hacı İsmail Ağa Fountain)}

Konut yapısına bitişik yapılan çeşme, kitabesine göre H. 1189 / M. 1775 y1lında Hacı İsmail Ağa tarafından yaptırılmıştır. Bir konut yapısının duvarına bitişik yapılan su hazineli çeşmenin özgün teknesi günümüzde yol seviyesiyle aynı hizadadır. Kesme taştan yapılmış çeşme nişinin yekpare sütunlar üzerine oturan çift merkezli teğet kemer formunda çeşme aynalığ vardır. Çeşme aynalığının ortasına mermerden yapılmış kitabesi yerleştirilmiştir. Kitabenin günümüz Türkçe 
yazımı şu şekildedir: Sahibu'l-hayrat ve'l-hasenat merhum ve mă̆fur / El-mubtaç ila rahmeti rabbibi'l-gafûr İslamboli Badastanî / El-bac Ismail Ağa rubiçun maaen lillahill-fatiba / Hicri Fi 1 Cemaziyülevvel sene 1189 (Miladi 30 Haziran 1775). Çeşmenin musluk tablası tek lüleli büyük bir mermer levha şeklindedir. Tablaya bitişik sol üst tarafinda taslık nişi yapılmıştır. Çeşme yüzü sütunlarda selvi ağacı motifi, kemerde içe doğru bordür ve kilit taşında altı uçlu yıldız motifi ile süslenmiştir. Çeşmenin az müdahale görmüş olması, özgün elemanlarının ve süslemelerinin günümüze ulaşmasını sağlamıştır. Ancak bakımsızlıktan su haznesinin tonoz üst örtüsü çökmüştür.

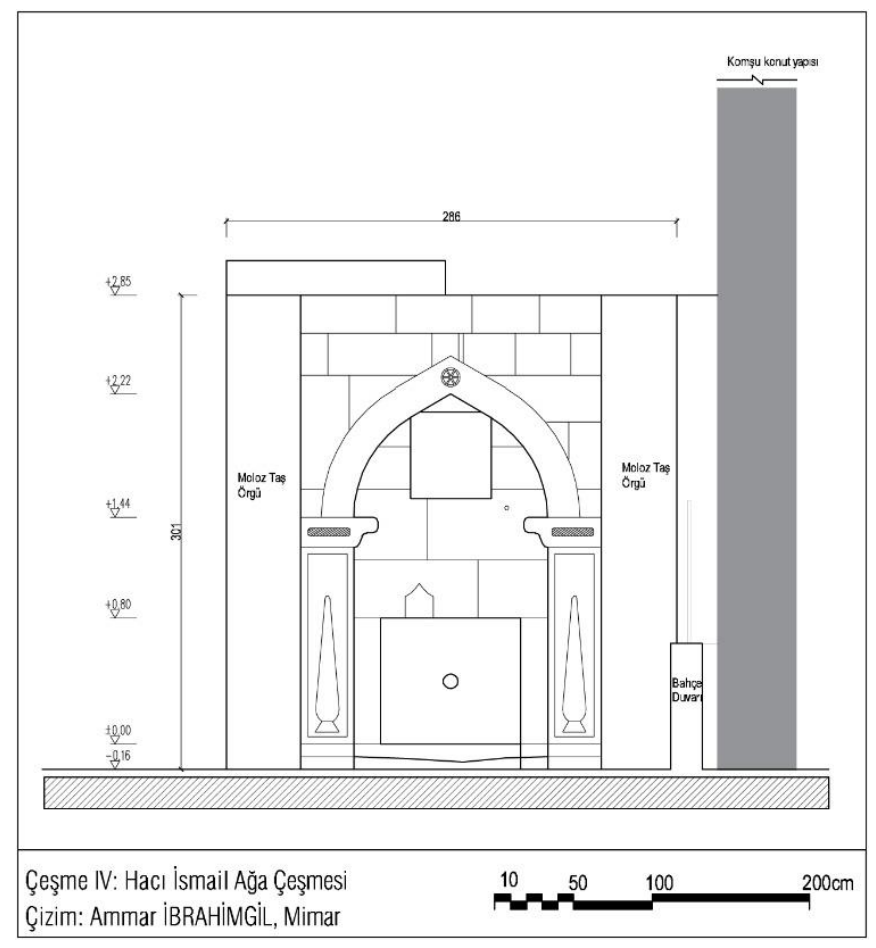

Şekil 6: Çeşme IV ön cephe çizimi (Fountain IV, front elevation drawing)
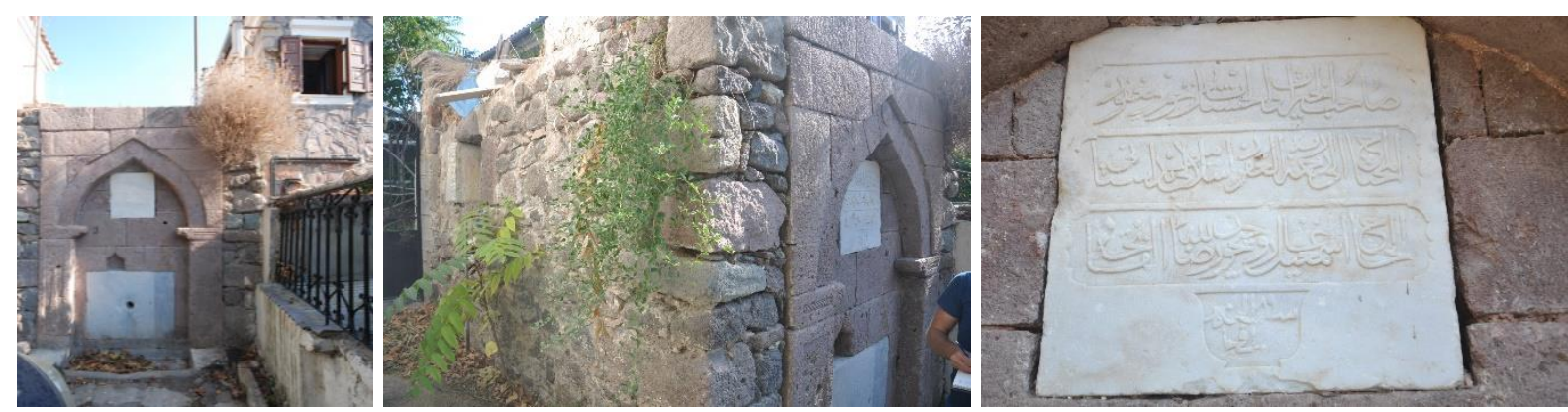

Resim 5: Çeşme IV (1775); İsmail Ağa Çeşmesi genel görünümü (General view of Fountain IV)

\section{Çeşme V - 1861 (Fountain V)}

Molivos'taki hamam duvarına bitişik şekilde, kitabesine göre H. 1278 / M. 1861 yllında yaptırılmıştır. Kitabede baninin yazıldığı satır, zaman içinde gördüğü tahribattan dolayı okunamamıştır. Ön yüzünde sütunlar, sütun başlıkları ve kemer köşelikleri yekpare taş bloklardan 
yapılmıştır. Çeşme aynalığı çeyrek dairelerden karşılıklı bir içbükey, bir dışbükey ve tekrar içbükey üç dilimli kemer forma sahiptir. Çeşme aynalığına yerleştirilen 3 satırlı kitabenin günümüz Türkçe yazımı şu şekildedir: Kerim içer ise bu âb-ı / Naib ola ona cennet ...(?) / Sabibu'l-hayrat ve'l-hasenat / Sene 1278 (Miladi 1861-1862). Taştan yapılmıs musluk levhası tek lülelidir. Musluk levhası ile kitabe arasında ikisi sağır biri taslık olan üç kap nişi yapılmıştır. Çeşme cephesinde sütunlarda birer selvi ağacı motifi ile kemer köşeliklerinde birer çarkıfelek motifi ile süslenmiştir. Çeşmenin özgünlüğü genel olarak korunabilmiştir. Ancak bakımsızlıktan yıpranmış olduğu gözlenmiştir. Yer yer malzeme kayıpları ve kireç izleri görülse de kitabesi, süslemeleri büyük ölçüde günümüze ulaşabilmiştir.

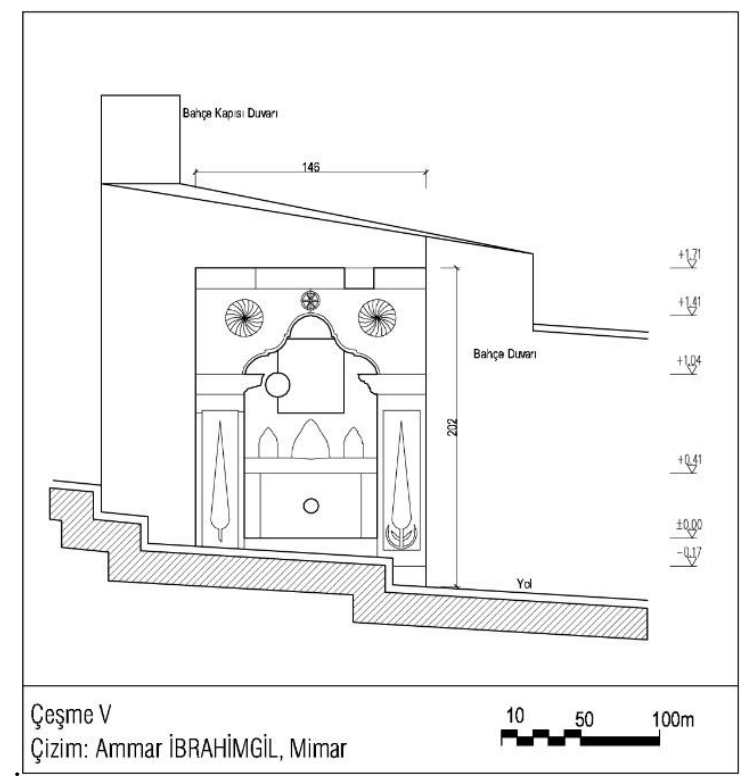

Şekil 7: Çeşme V ön cephe çizimi (Fountain V, front elevation drawing)
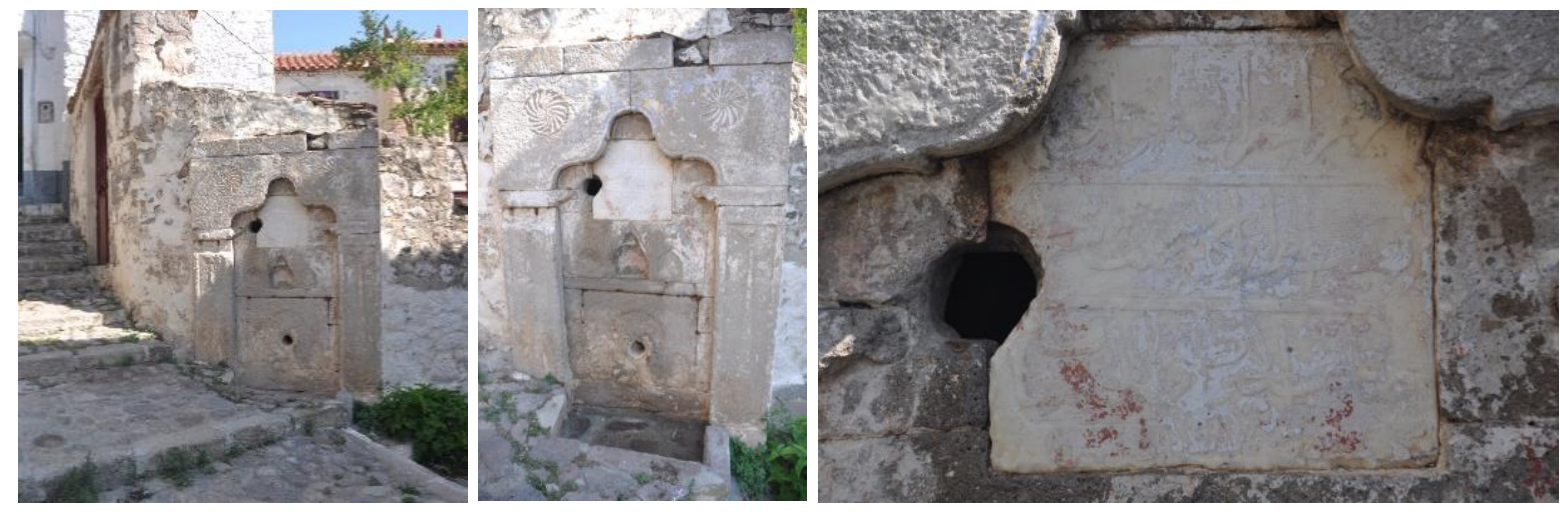

Resim 6: Çeşme V (1861)'in genel görünümü (General view of Fountain V)

\section{Çeşme VI: Hacı Mustafa Ağa Çeşmesi - 1884 (Fountain VI: Hacı Mustafa Ağa Fountain)}

Çeşmenin sol duvarı bir konut yapısına bitişiktir. Sağından ise merdivenler yükselmektedir. Çeşme kaba yonu kesme taştan yapılmıştır. Çeşme nişi, çeşme ön cephesine oturtulan yekpare taşlarla 
yapılmıştır. Taş örgüsü yönünden V. çeşmeye benzemektedir. Çeşme aynalığ1 karşılıklı dış bükey ve iç bükey dört daire yayından yapılmış yarım daire olarak birleşmektedir. Aynalığın ortasında Osmanlıca ve Yunanca mermerden kitabesi yer alır. Kitabesinin günümüz Türkçe yazımı şu şekildedir: Kalellabu Te'âlâ "Vesekâbum rabbubum şarâben tahûrâ"” / Monla (Molla) Abdullab Hoca Ahmet'in oğlu Hacı / Mustafa'nun hayratı Fî gurre / Rumi 1 Mart Sene 1300 (Miladi 1 Mart 1884) Yunanca Yazılmış Kitabesi - Hacı Abmet oğlu / Hacı Mustafa / 1884. Çeşmenin tek lüleli musluk tablasının hemen üstünde kap nişi vardır. Kemerin altındaki yekpare sütunlar, dinlenme sekilerinin üstüne oturmaktadır. Çeşmenin su teknesi ise yerdedir. Ön ve yan yüzeylere taşkın sütun başlığının bir kepçeli silmesi vardır. Aynı şekilde çeşmenin üst silmesi de bir kepçelidir. Bu çeşmenin diğer bir özelliği ise vakfiyesinin olmasıdır. Vakfiyesine göre Hacı Mustafa'nın torunu Hacı Numan Ağa, bu çeşmeyi tamir ettirdiğinde Molova ve çevresindeki bütün çeşmeleri de tamir ettirmiştir. VGMA, Df. No: 987, Sh. No: 177-179, Sira No: 56 / 1'de kaynth, Hicri 1 Mubarrem 1233 / Miladi 11 Kasım 1817 tarihli Hacı Mustafa Ağanın torunu Hacı Numan Ağa’ya ait vakfiyede, Molova civar köylerinde Hacı Mustafa Ağa tarafından inşa edilen birçok çeşmenin ve suyollarının tamir ve bakım masraflarını karşılanması için vakıf geliri bıraktığından bahsedilmektedir. Çeşme yüzeyindeki izlerden, bir zaman kireçle sıvanmış olduğu anlaşılmaktadır. Büyük ölçüde özgünlügü korunmuş yapının, bakıma ihtiyacı vardır.

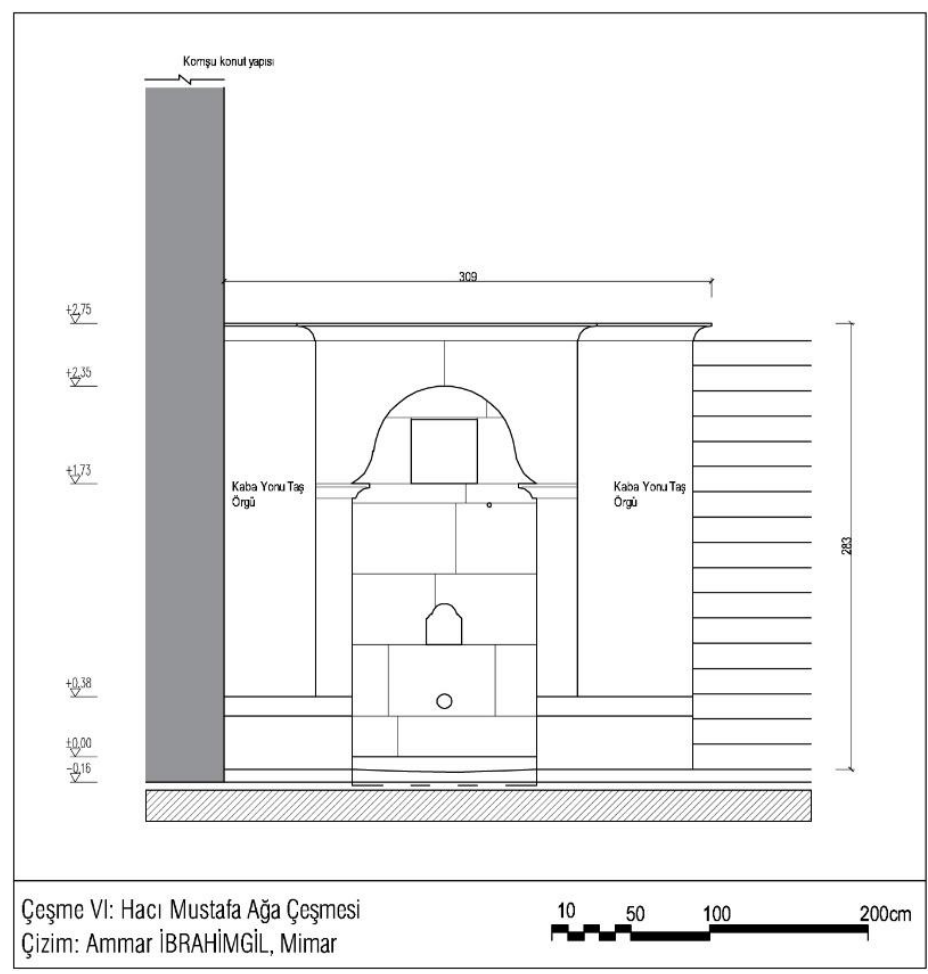

Şekil 8: Çeşme VI ön cephe çizimi (Fountain VI, front elevation drawing)

\footnotetext{
1 İnsan Suresi 21. Ayet Meali: “ ... Rableri onlara tertemiz bir içecek içirecektir.” (DİB Kur’an-1 Kerim Meali)
} 

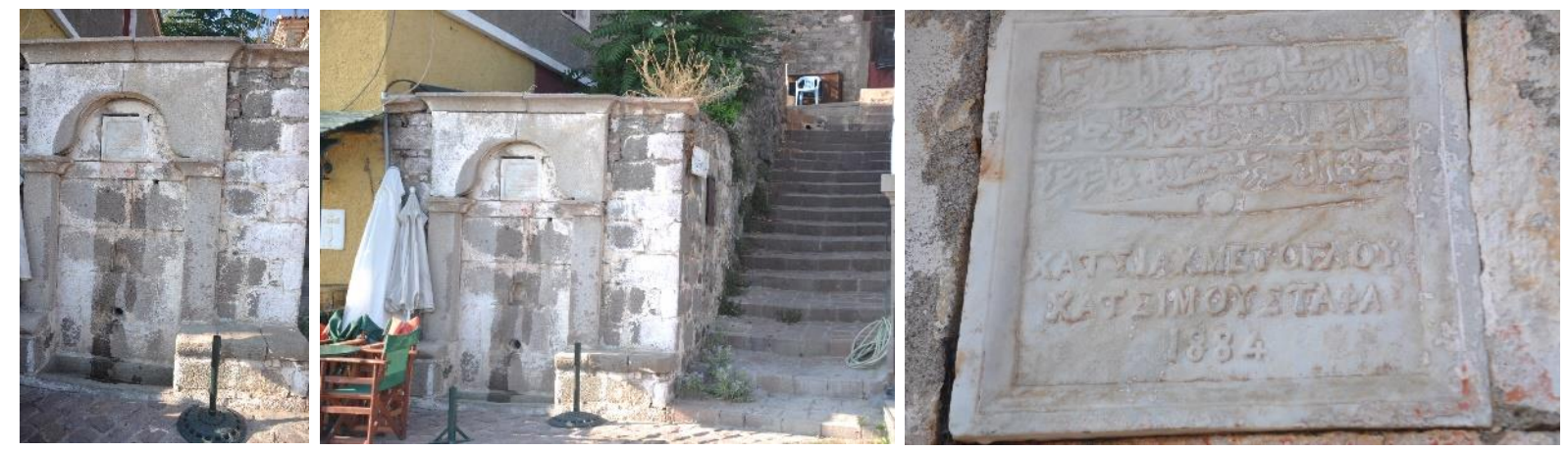

Resim 7: Çeşme VI (1884); Hacı Mustafa Ağa Çeşmesi genel görünümü (General view of Fountain VI)

\section{Çeşme VII: Hükümet Çeşmesi - 1900 (Fountain VII: Government Fountain)}

Osmanlı dönemi yapılan mahkeme binasının yakınlarında bulunmaktadır. Meydan çeşmesi olarak kesme taştan yapılan çeşmenin 4 cephesinden sadece iki cephesinde çeşme nişi vardır. Çeşme nişlerinden daha üst kota bakan cephesinde ikişer sütun bulunmaktadır. Sütunlardan içte olanın üstünde şerit silmelerden yapılmış sütun başlıkları ve onun da üstünde yarım daire formunda kemer oturtulmuştur. Kemerin kilit taşı hafif yüksekçedir. Dıştaki sütunlar ise birbirine bindirilmiş bir uzun bir kısa ikişer sütundan yapılmıştır. Uzun sütun içtekiyle beraber uzanmakta ve başlıklar birleştikten sonra çeşmenin silmesine kadar devam eden daha küçük ikinci sütun oturtulmuştur. Silmenin altında ampir süslemeli sütun başlıkları vardır. En nihayet çeşmenin silmesi de ampir üslupta yapılmıştır. Silmenin üstünde de mermerden üçgen alınlık vardır. Kesme taş ile çevrelenmiş mermer alınlıkta iki kenarında ay-yıldız motifi arasında inşa tarihi yazılımıştır. Kitabesine göre çeşme Rûmî Sene19 Ağustos 1316 (Miladi 1 Eylül 1900) yllında inşa edilmiştir. Çeşme nişinin içi iki düz mermer levhadan yapılmışır. En altta yatay bir şekilde yerleştirilen musluk tablası zaman içinde çok hasar almıştır. Taşta yer yer kopmalar ve beton ile müdahaleler görülmektedir. Alt kota bakan cephede çeşme nişi ön yüze tutturulan birer sütunla yapılmıştır. Yekpare taştan yapilan sütunun üstünde ampir üslupta benzer sütun başlıkları yerleştirilmiştir. Çeşme aynası yarım daire şeklindedir. Çeşme nişi yekpare taşlarla örülmüştür. En alttaki taş aynı zamanda tek lüleli musluk tablasıdır. Su teknelerinin kenarlarında dinlenme sekileri yapılmıştır. Çeşmenin üstünde bir giriş vardır ve etrafı dört baba tarafından tutulan korkuluklarla çevrelenmiştir. Çeşmede mermer, andezit ve ponza taş1 gibi farklı tipte taşlar kullanılmıştır. Bakımsız kalan çeşme yapısı özgün karakterini büyük ölçüde korumaktadır. Hatta çift ay yıldız motifi günümüze kadar ulaşabilmiştir. 


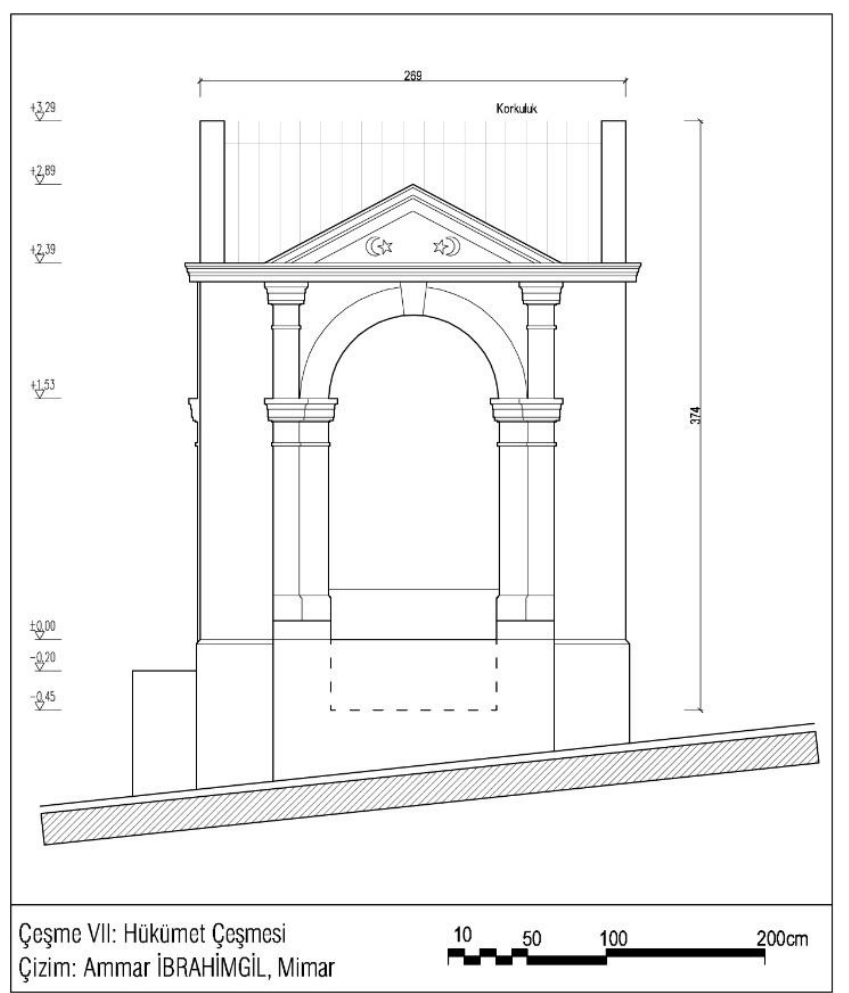

Şekil 9: Çeşme VII ön cephe çizimi (Fountain VII, front elevation drawing)
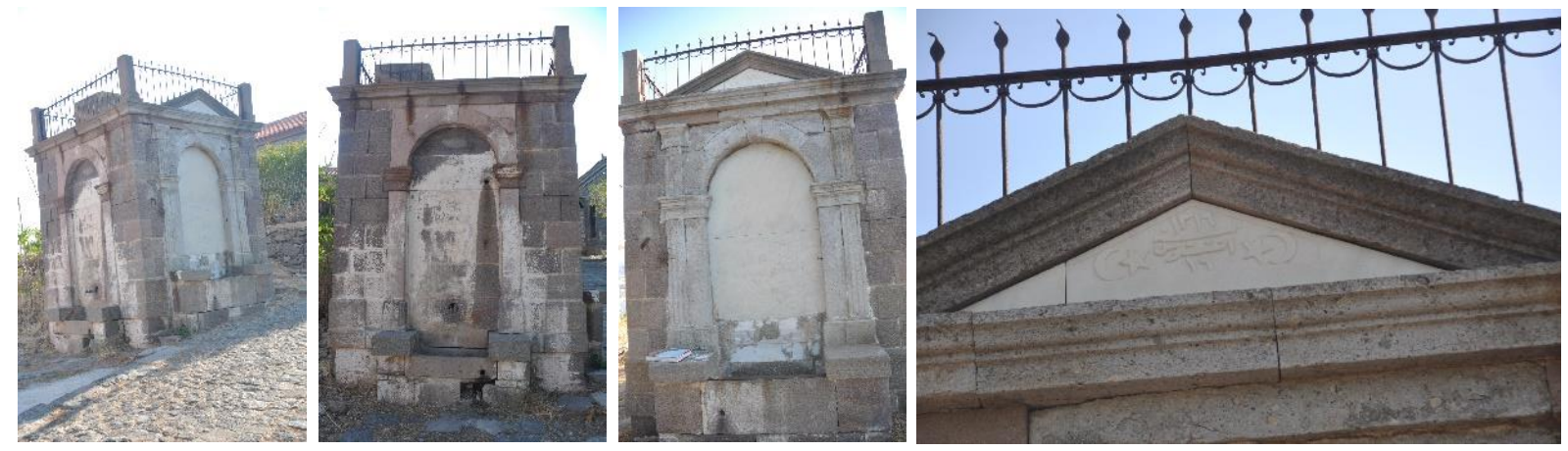

Resim 8: Çeşme VII (1900); Hükümet Çeşmesinin genel görünümü (General view of Fountain VII)

\section{Çeşme VIII (Fountain VIII)}

Çeşme, caminin yakınında bir konutun alt tarafinda toprağa gömülü haldedir. Çeşmenin kitabesi günümüze ulaşamasa da caminin yapılış tarihi kitabesine göre H. Recep 1227 / M. Temmuz 1812'dir. Ancak bu, çeşme ile ilgili kesin bir bilgi olmadığından tarihsiz çeşmeler grubunda sayılmıştır. Kesme taştan yapılmış çeşmenin derin bir nişi vardır. Çeşme aynası çift merkezden çizilen teğetli (mümaslı) kemerle çevrelenmiştir. Kemer yayını takip eden kemerbend hizasından sonra köşe tablaları dışa taşırılmışır. En dışta da tek kanaldan oluşan bir pilastr ile çeşme üç yönden de çerçeve içine alınmıştır. Çeşme aynasının ortasında kitabe yeri olmasına karşın kitabesi günümüze ulaşamamışır. Mermer taştan yapılmış tek lüleli musluk tablasının üstünde bir kap nişi 
vardır. Üzengi hattında içe doru taşırılmış yastıklar bulunmaktadır. Çeşmenin su teknesi yere yakındır ve sol yanında öne uzanan bir dinlenme taşı yapılmışı̧. Çeşme fiziki biçimlenme yönünden korunmuş olsa da kitabesi günümüze ulaşamamıştır.

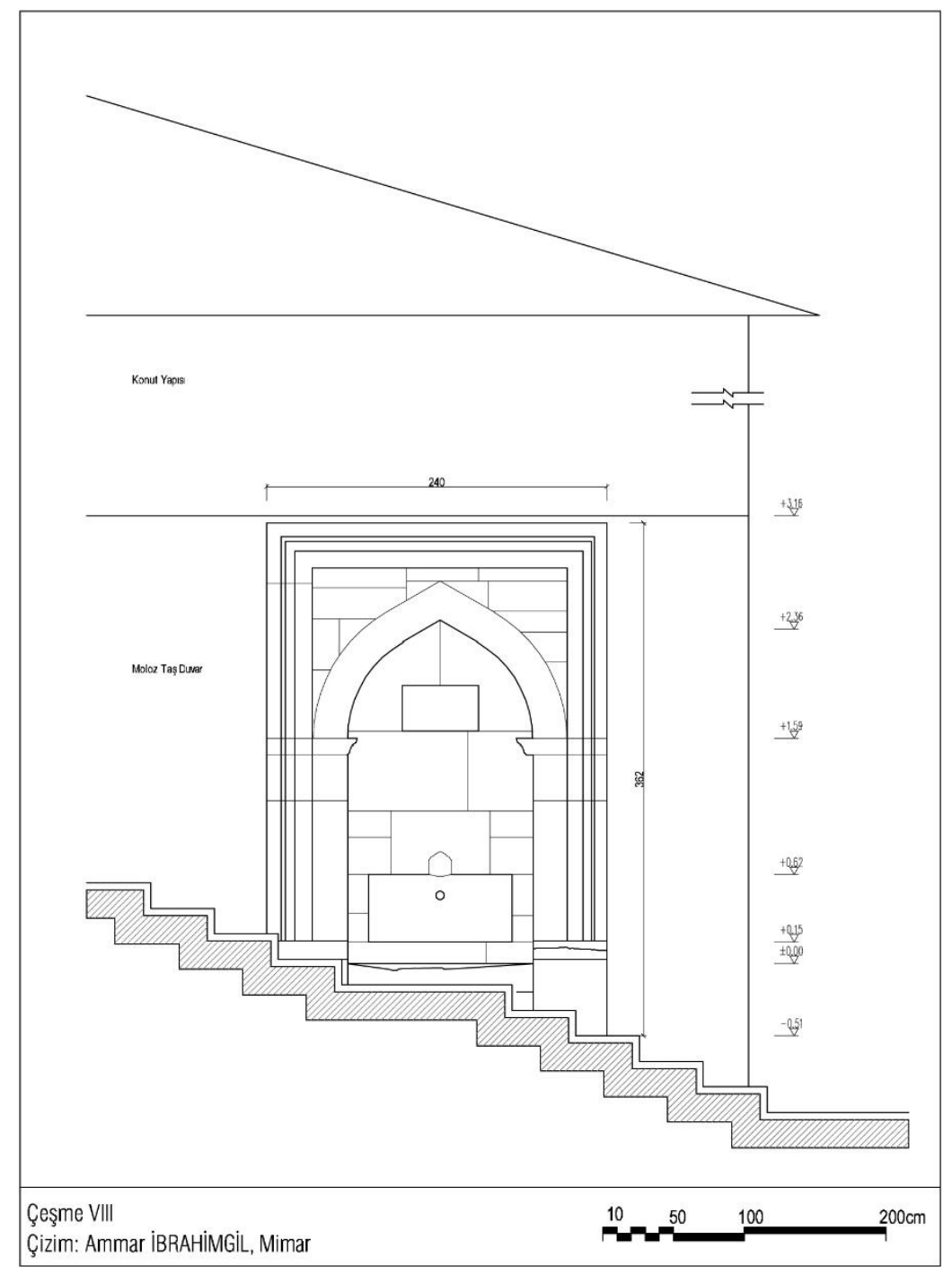

Şekil 10: Çeşme VIII ön cephe çizimi (Fountain VIII, front elevation drawing) 

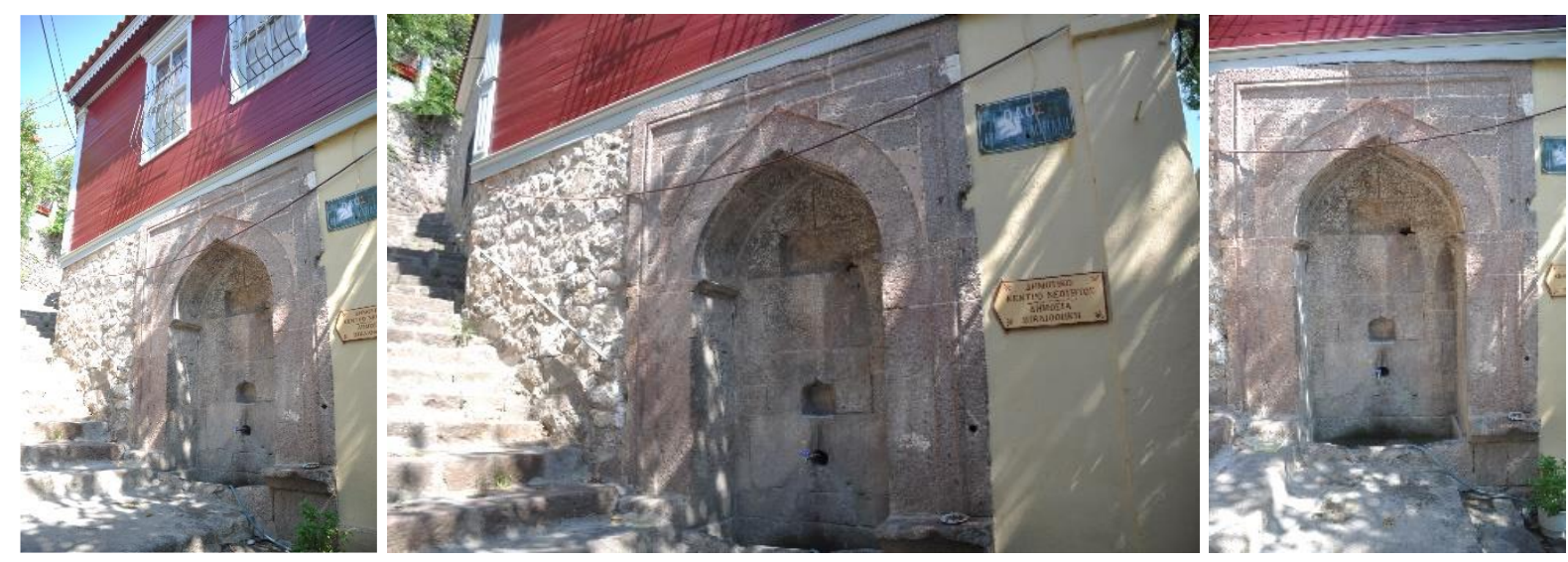

Resim 9: Çeşme VIII'in genel görünümü (General view of Fountain VIII)

\section{Çeşme IX (Fountain IX)}

Duvara bitişik çeşme grubuna dâhildir. Tek yüzlü çeşmenin sol tarafından çıkan yan duvar arkaya doğru kavis yaparak konut duvarıyla birleşmektedir. Su hazinesi tonoz ile örtülüdür. Fizikî biçimlenişi Çeşme VIII'e benzemektedir. Geniş bir çeşme nişi ve çift merkezden çizilen teğetli (mümaslı) kemerle çevrelenmiş aynası vardır. Mermerden yapılmış musluk tablası özgün halinde üç lüleli iken zaman içinde özgün yerinden daha aşağıda açılan başka bir lüle deliğinden hizmet vermeye devam etmektedir. Çeşmenin teknesi yerde olup, kenarlarında birer dinlenme sekisi bulunmaktadır. Kasabadaki en özgün halini yansıtan çeşmedir. Çeşme, en üstte dışa taşan bir silme ile taçlandırılmıştır.

Büyük ölçüde özgünlüğünü koruyan çeşmenin, nişindeki taşların daha fazla yıprandığı görülmüştür. Günümüzde de aslî işlevini sürdürmektedir. Yapının tonoz örtülü çatısında bitkilenme vardır. Ayrıca bina ile kesişen kenar boyunca çimento dökülmüştür.
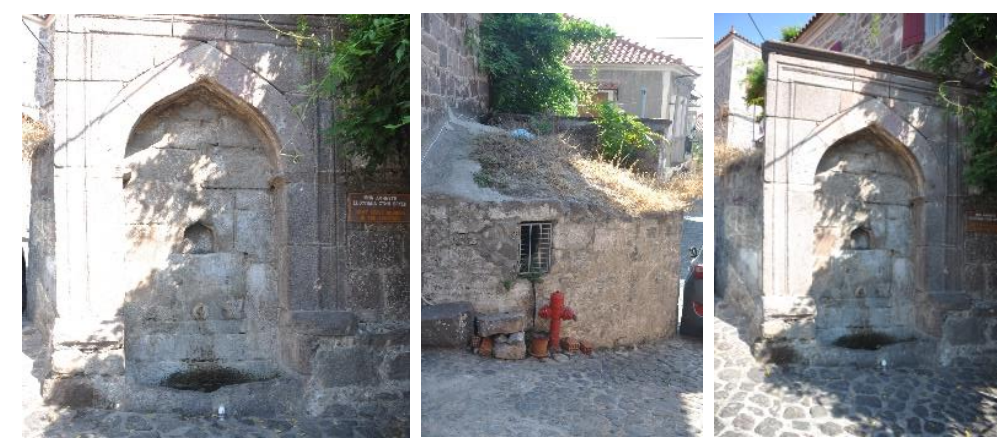

Resim 10: IX'un genel görünümü (General view of Fountain IX) 


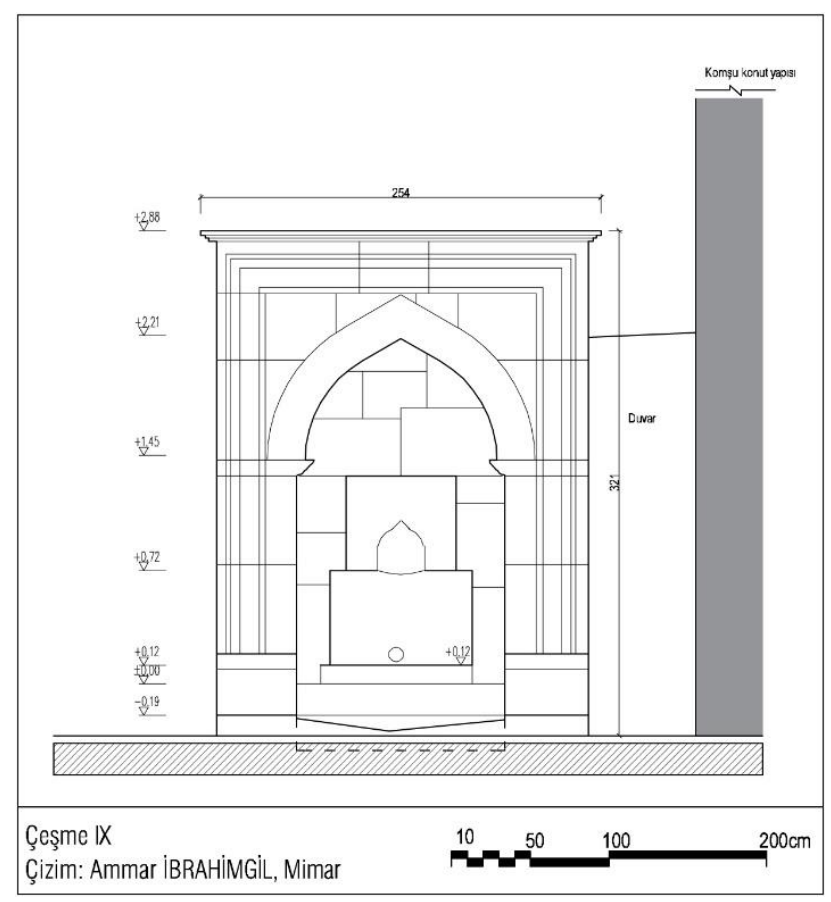

Şekil 11: Çeşme XI ön cephe çizimi (Fountain XI, front elevation drawing)

\section{Çeşme X (Fountain X)}

Çeşme, iki konut yapısı arasında, köşe bir noktada bulunur ve su haznesinin üstü avlu olarak kullanılmaktadır. Çeşme aynası iki yekpare kesme taş sütuna oturan penci kemerle yapılmıştır. Yekpare taştan yapılmış tek lüleli musluk tablasının altında mermer bir taş yerleştirilmiştir. Musluk tablasının üstünde büyük bir kap nişi açılmıştır. Aynı şekilde yekpare taştan yapılan teknesi yerden hafif yüksek şekilde konumlandırılmışır. Çeşme, koruma durumu yönünden birçok bilinçsiz müdahale geçirmiştir. Meydana gelen hasarları onarmak için yer yer çimento sıva kullanılmıştır. Benzer şekilde soldaki dinlenme taşı tamamen yok olmuş, onun yerine betondan benzer formda yeniden yapılmıstır.
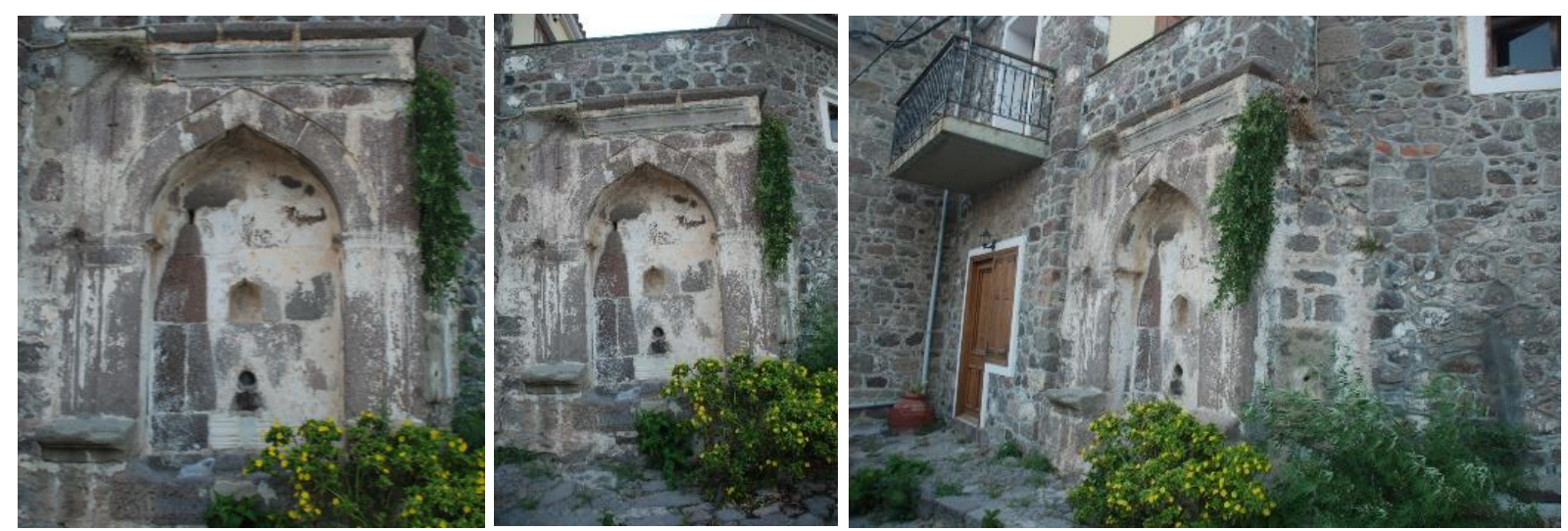

Resim 11: Çeşme X'un genel görünümü (General view of Fountain X) 


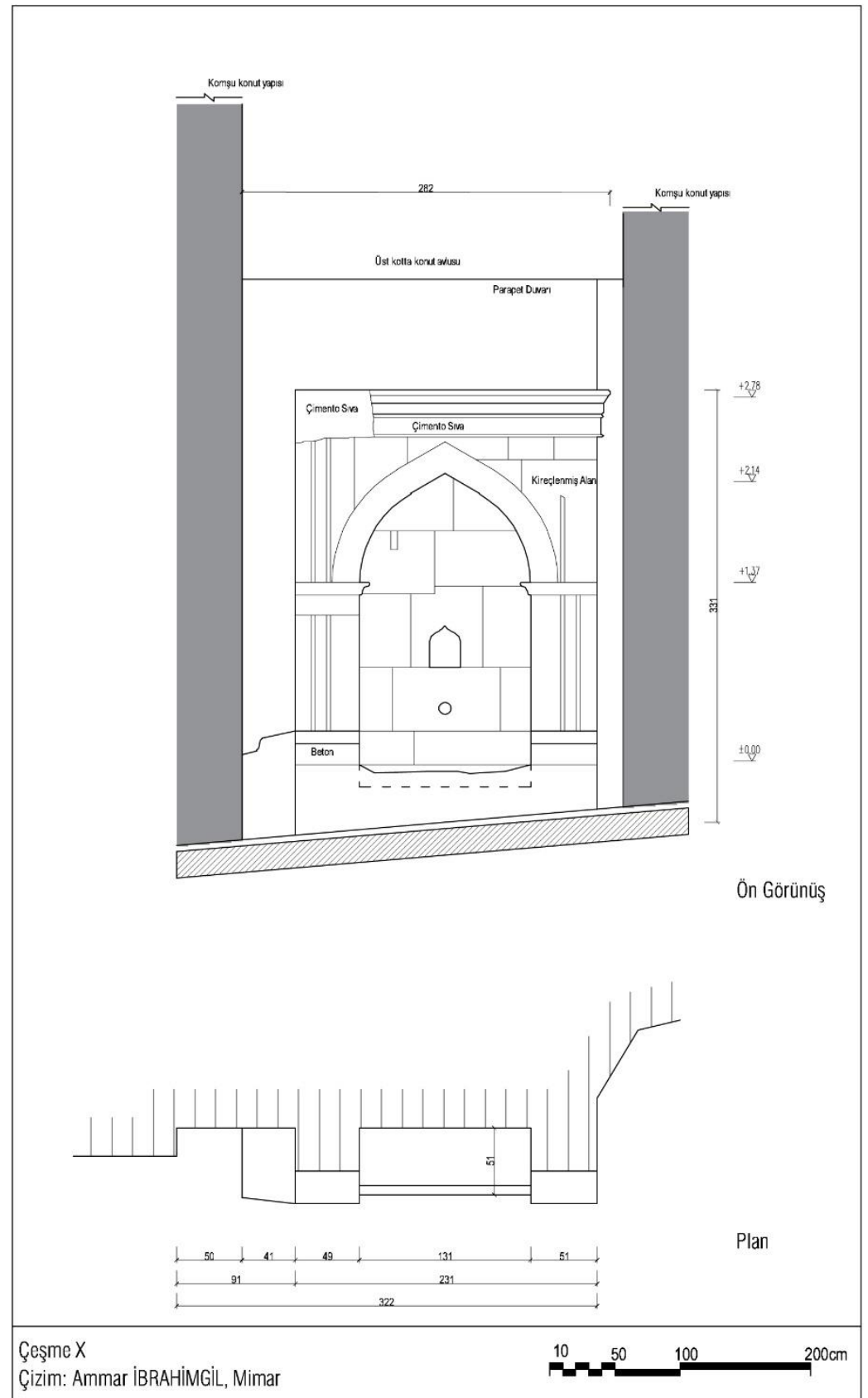

Şekil 12: Çeşme X ön cephe ve plan çizimi (Fountain X, front elevation and plan drawing)

\section{SONUÇ (CONCLUSION)}

Molova'da incelenen on çeşme yapısı içerisinde Çeşme I, H.1122 / M. 1710 en erken tarihlidir. En yakın tarihli ise Çeşme VII (Hükümet Çeşmesi), R. 1316 / M. 1900 tarihlidir. Buna göre Osmanlı döneminde 18. yüzyılın başından 20. yüzyıla kadar bu bölgede birçok hayrat yapılmıştır. 1700'lü yıllar Osmanlı sanatında Batı motiflerinin sızmaya başlandığı dönemdir. Türk Sanatı, o sırada Batı'da hakim olan barok üslubunun etkisinde kalmıştır. Mimaride de kendine alan bulan bu üslup, özellikle çeşme yapılarında göze hoş gelen eserlerin ortaya çıkmasını sağlamıştır. Semavi Eyice'ye göre bu dönemin en abidevi eseri Ayasofya şadırvanı ile Tophane'deki meydan çeşmesidir (Eyice, 
2011, s. 59). 18. yüzyıldan itibaren İstanbul'da yapılan çeşmeler, malzeme ve süsleme yönünden gözü alan birer sanat eseri olarak, o dönemin çağdaş sanatını yansıtan vitrinlere dönüşmeye başlamıştır (Kanlıçay, 2010, s. 6). İstanbul'da 18. yüzyılda yapılmış III. Ahmet Çeşmesi (1728) ile 19. yüzyılda yapılmış Pertevniyal Valide Sultan Çeşmesi (1863) dönem özelliklerini yansıtan en önemli örneklerdir (Pilehvarian, 2002, s. 248). 1700’lerden başlayan ve 1900'lere kadar uzanan bu 200 yıl zarfinda Molova'da yapılan çeşmelerde 18. yüzyıldan başlamak üzere İstanbul ve diğer birçok önemli yerde kendini gösteren barok - rokoko tarzı Batı etkisinde bir anlayış gözlenmemiştir. Klasik dönemin sabit kurgulu çeşme şemasının hâkim olduğu görülmüştür. İstanbul'da Kırkçeşmeler, Küçük Ayasofya'daki Rüstem Paşa Çeşmesi (H.962/M.1554) örneklerinde olduğu gibi tek yüzlü duvar çeşmeleri tipindedir. Çeşmelerin hepsi de bulundukları mahallenin su ihtiyacını karşılamaya yöneliktir. Buna göre çeşmelerde mimari tasarım ve patronage etkisinden çok su gereksiniminin karşılanması ve hayır dua alınması önceliği korunmuştur.

Karşılaştırmalı örneklemede konunun dağılmaması için Osmanlı'nın Cezayir-i Bahri Sefîd Eyaleti içinde benzer coğrafya, nüfus yapısı ve siyasi etkiler dikkate alınarak Sakız ve Rodos adalarındaki çeşme örnekleri incelenmiştir. Rodos'ta 1756 tarihli Faralyalı Çeşmesi, 1880 tarihli Enderun Çeşmesi ve 19. yüzyılda yapılmış Tersane Çeşmesi ile Sakız Adası'ndaki Melek Ahmet Paşa Çeşmesi İstanbul'daki dönem örneklerine benzer şekilde barok etkisiyle çok süslü ve işlemeli yapılmışır (İbrahimgil A. , 2019). Buna karşılık Sakız adasında Sultan Abdülmecid Çeşmesi (1850) ve Rodos adasındaki Hamdi Bey Çeşmesinde (1846) görülen klasik üslup, Osmanlı çeşme mimarisinde barok - rokoko dişında klasik üslubun da devam ettirildiğini göstermektedir (İbrahimgil \& İbrahimgil, 2019, s. 271).
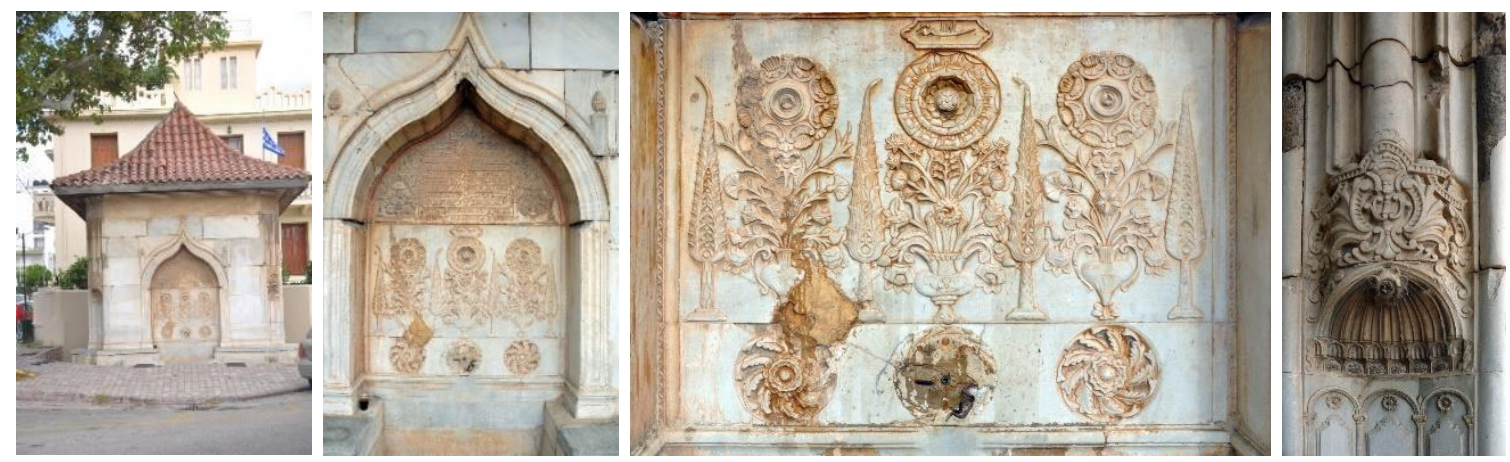

Resim 12: Sakız Adası'nda barok-rokoko tarzında yapılmıs 1770 tarihli Melek Mehmet Paşa Çeşmesi (Melek Mehmet Pasha Fountain, built in baroque-rococo style in 1770, in Chios) 

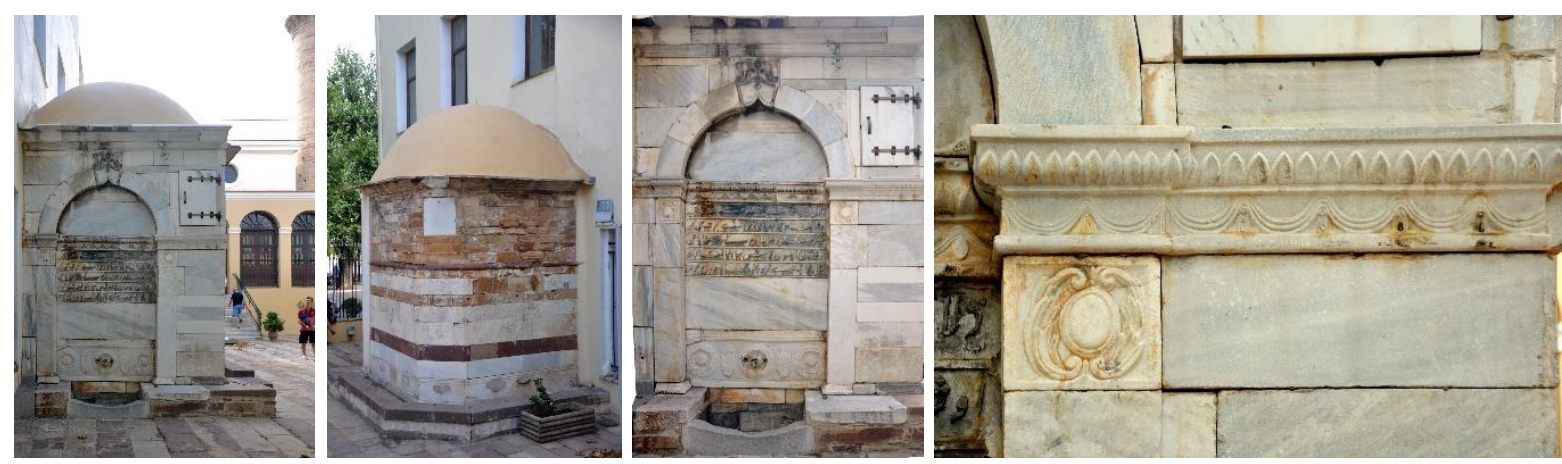

Resim 13: Sakız Adası'nda süs unsurları Barok üsluptan alınmış ve Türk Klâsik çeşme cephesi ölçülerine uydurulmuş 1850 tarihli Sultan Abdülmecid Çeşmesi (The Sultan Abdulmecid Fountain dated 1850, whose ornamental elements were taken from the Baroque style and adapted to the dimensions of the Turkish Classical fountain front in Chios)
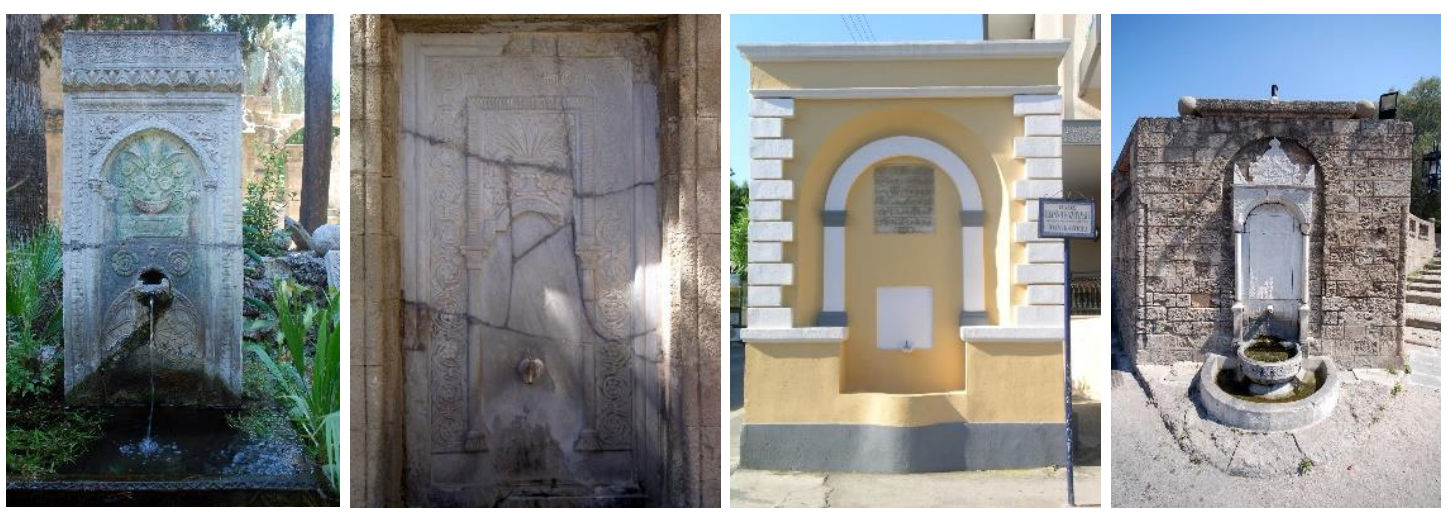

Resim 14: Rodos'ta yapılan 1756 tarihli Faralyalı Köşkü bahçe çeşmesi, 1880 tarihli Enderun Çeşmesi, 1845 tarihli Hamdi Bey Çeşmesi ve 19. Yüzyılda yapılmış Tersane Çeşmesi görülmektedir (The garden fountain of the Faralyalı Mansion dated 1756, the Enderun Fountain dated 1880, the Hamdi Bey Fountain dated 1845 and the Shipyard Fountain built in the 19th century are seen respectively)

Molova'da incelenen çeşmelerin hepsi mahallelerin su ihtiyacını karşılayan mahalle çeşmeleridir. Yerleşim dokusunda homojen sayılabilecek bir dağılım sergilemektedir. Çeşmelerin yapıllış tarihleri ile konumlanmaları yerleşim alanının bir bölgesinde olmayıp, çok yakın tarihlerde yapılan çeşmeler dâhi biribirinden uzaktadır. Bu da artan Müslüman nüfusun sadece göçten kaynaklanmadığını, bir dönem ihtida ile İslâmiyet'e geçişlerin olduğunu göstermektedir. Çeşmelerin konumlanmasında en dikkat çekici durum Çeşme I ve Çeşme VIII çarşı yolu üzerinde yapılmışken, diğer çeşmeler yerleşim alanlarının farklı yerlerine dağılmış olmasıdır. Bunun yanında Çeşme VIII, yerleşim yerinin bitişinde en yakın tarihli çeşmedir. 


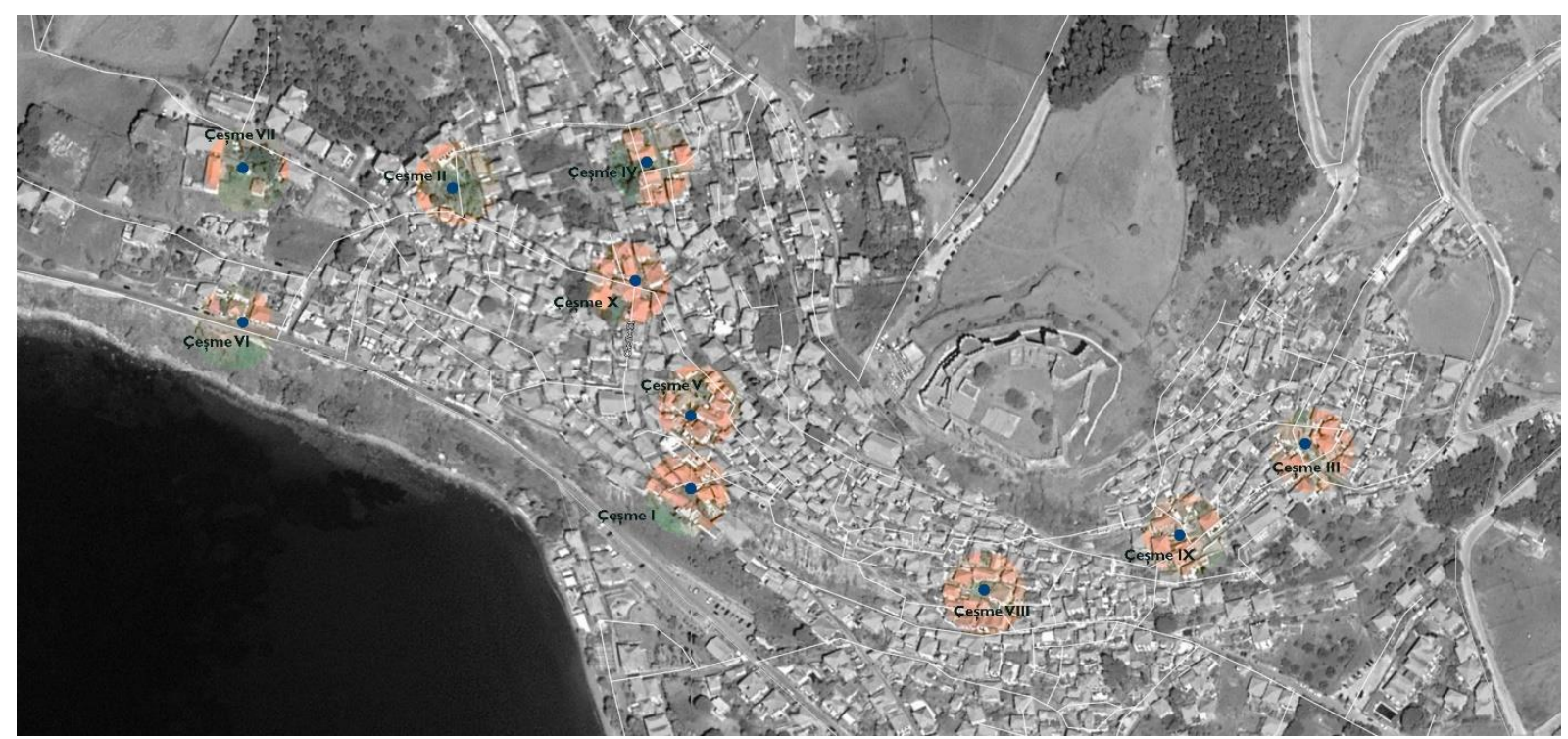

Şekil 13: Molova Çeşmeleri'nin yerleşim dokusundaki dağılımı (Distribution of Molova Fountains in settlement texture)

Çeşmelerin tipolojik çözümlenmesinde konumuna göre toprak altında olan beş çeşmeden 4'ünün (I, III, VI, X) üstü avlu olarak kullanılırken bir tanesinin (VIII) üstünde konut yapısı bulunmaktadır. Toprak üstünde olan diğer beş çeşmeden iki tanesi (II, VII) meydan çeşmesi şeklinde yapılmışken, diğer 3 çeşme (IV, V, IX) en az bir duvara bitişik yapılmıştır.

Çeşmelerin fizikî biçimlenişi ise üç başlıkta incelenmiştir. Çeşmelerden birisi hariç (VII) hepsi tek cephelidir. Plan biçimlenmesine göre ise su haznesi toprak altında olan çeşmelerin, su haznesinin üst örtüsü taşıdığı hareketli yük dolayısıyla düzgün çokgen bir yapıda olduğu kabul edilmiştir. Su haznesi duvara bitişik olan Çeşme V ve Çeşme IX'un planı ise amorf bir şekle sahiptir. Çeşme ön yüzüne göre ise çeşmelerden 7 tanesi (I, II, III, V, VI, VII, X) duvar hizasından öne doğru taşırılmış, 3 tanesi ise (IV, VIII, IX) duvarın içinde yapılmıştır.

Çeşmelerin bir diğer karakteristik özelliği olan çeşme aynasının kemer biçimlenişine göre en erken tarihli Çeşme I, dilimli üçgen bir aynalığa sahiptir. Bunun dışında altı çeşme aynası (II, IV, VIII, IX, $\mathrm{X})$ penci kemerle, iki adet çeşme aynası (III, VII) yarım daire kemerle yapılmışen, geriye kalan çeşmelerden Çeşme V'te, üç yay dilimli, Çeşme VI'da çift yaylı çeşme aynalığı yapılmıştır.

Diğer taraftan sadece iki çeşmenin (VIII, IX) sütunları yekpare taştan değildir. Çeşmelerin süsleme durumu incelendiğinde ise çarkıfelek, altı kollu yıldız, selvi ağacı ve burgu ile ay yıldız motifi karşımıza çıkmaktadır. 1861 yılında yapılan Çeşme V en süslüsüdür. Çeşme sütunlarında selvi ağaçları, sütun başlıklarında burgu ve niş yanaklarında büyük birer çarkıfelek motifi ile süslenmiştir. Bunun dışında iki çeşmede (II, IV) çarkıfelek süsleme vardır. Bunların dışında 1900'de yapılan çeşmede üçgen alınlığa karşılıklı yapılan ay yıldız motifi dikkat çekicidir. Bu çeşmenin Osmanlı dönemi idari binasının avlu önünde olması, bu çeşmenin kamu yatırımı ile yapıldığını göstermektedir. 
Tablo 3: Malova'daki çeşmelerin tipolojik tablosu (Typological table of the fountains in Molyvos)

\begin{tabular}{|c|c|c|}
\hline \multicolumn{3}{|l|}{ A. Konumuna Göre } \\
\hline \multirow{2}{*}{ 1. Su haznesi toprak altında } & a. Üstü Avlu & Çeşme - VIII \\
\hline & b. Üstü Konut & Çeşme - I / III / VI / X \\
\hline \multirow{2}{*}{ 2. Su haznesi toprak üstünde } & a. Duvara Bitişik Çeşme & Çeşme - IV / V / IX \\
\hline & b. Meydan Çeşmesi & Çeşme - II / VII \\
\hline \multicolumn{3}{|l|}{ B. Fizikî Biçimleniş } \\
\hline \multirow{2}{*}{ 1. Cephe Say1s1 } & a. Tek Cepheli & Çeşme - I / II / III / IV / V / VI / VIII / IX / X \\
\hline & b. Çok Cepheli & Çeşme - VII \\
\hline \multirow{2}{*}{ 2. Plan Tipi } & a. Çokgen Planlı & Çeşme - I / II / III / IV / VI / VII / VIII / X \\
\hline & b. Amorf Planlı & Çeşme - V / IX \\
\hline \multirow{2}{*}{ 3. Çeşme Yüzü } & a. Duvardan Dışa Taşkın & Çeşme - I / II / III / V / VI / VII / X \\
\hline & b. Duvarın İçinde & Çeşme - IV / VIII / IX \\
\hline \multicolumn{3}{|l|}{ C. Aynalık Tipleri } \\
\hline \multicolumn{2}{|l|}{ 1. Penci Kemer Aynalık } & Çeşme - II / IV / VIII / IX / X \\
\hline \multicolumn{2}{|l|}{ 2. Yarım Daire Kemerli Aynalık } & Çeşme - III / VII \\
\hline \multirow{2}{*}{ 3. Dilimli Kemer Aynalıklar } & Çift Dilimli Kemer & Çeşme - VI \\
\hline & Üç Dilimli Kemer & Çeşme - I \\
\hline \multicolumn{2}{|l|}{ Üçgen Aynalık } & Çeşme - V \\
\hline
\end{tabular}

Molova'daki 10 çeşmeden 7'sinin tarihi kesin olarak tespit edilmiştir. Bunun dişında kalan üç çeşme (VIII, IX, X) için tarihlendirmede karakteristik bir eleman olan çeşme aynasının kemer biçimlenmesi esas alınmıştır. Buna göre 18. yüzyılda yapılan çeşmelerden (I, II, III, IV) Çeşme I hariç hepsinin çeşme aynası penci kemerlidir. Ayrıca özellikle Çeşme V (1861) ve Çeşme VI (1884)'da benzer teknikle iki masif taşın yay şeklinde yontulduktan sonra bir araya getirilmesiyle çeşme aynasında kemer elde edilmiştir. Bu iki çeşme kemer oluşturma tekniği ile 18. yüzyıl çeşmelerinde ayrışmaktadır. 18. yüzyıl çeşmelerinde kemerbendler dâhil kemer örgüsü vardır. Buna göre tarihlenemeyen üç çeşme de 18. yüzyılda yapılmıştır.

Çeşmeler, genel itibariyle özgünlüklerini korumuştur. Zaman içinde yapılan bilinçsiz müdahaleler olsa da bir kısmının bilinçli restore edildiği de anlaşılmaktadır. Hemen hemen hepsinde yer yer malzeme kayıplanı dikkat çekmektedir. Ayrıca ada yerleşimlerinde sıkça rastlanan bir durum olan duvarları kireçle boyama burada da birçok çeşmede görülmektedir.

Osmanlı coğrafyasında taşra sayılan bu küçücük yerleşim yerinde onlarca eserin günümüze kadar ulaşması çok dikkat çekicidir. Molivos, Osmanlı'nın elinden çıktıktan sonra 20. yüzyılda önemini büyük ölçüde kaybetmiştir. Göç verilen bu fakirlik ve durağanlık döneminde sahip olduğu mimari değerleri elden geldiğince muhafaza ederek, Ege Bölgesi’nin en özgün şehirlerinden biri olarak kalmasını sağlamıştır.

\section{REFERANSLAR (REFERENCES)}

Aytöre, A. (1959). Türklerde Su Mimarisi. Milletlerarası Birinci Türk Sanatlar Kongresi Tebliğleri (s. 4569). İstanbul: KTB. 
Çeçen, K. (1999). İstanbul'un Vakerf Sularndan Üsküdar Sular. İstanbul: İSKİ.

Denktaş, M. (2012). Anadolu Türk Mimarisinde Çeşmeler. Türkler Anslikopedisi, s. 872-877.

Eyice, S. (1993). Çeşme. İslâm Ansiklopedisi, s. 277-286.

Eyice, S. (2011). İstanbul'un Kaybolmuş Önemli Bir Tarihi Eseri: Fatih’te Sultan I. Mahmud Çeşmesi. Restorasyon ve Konservasyon Çalışmalar Dergisi, 49-59.

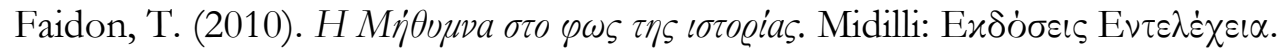

İbrahimgil, A. (2019). Founains of the Ottoman Period In Chios Island. 2. Uluslararası Islami Mimari Miras Konferansı (s. 281-301). İstanbul: Fatih Sultan Mehmet Vakıf Üniersitesi.

İbrahimgil, M., \& İbrahimgil, A. (2019). Rodos Adası'nda Osmanl Mirası. Ankara: Atatürk Kültür Merkezi.

Kanliçay, S. S. (2010). Barok-Rokoko Yorumlu 18. Yüzynl Istanbul Ceşmelerinde Kompozisyon, Motif ve Terimler (1740-1797). İstanbul: İTÜ Sosyal Bilimler Enstitüsü Yüksek Lisans Tezi.

Karaağaç, İ. (2019). Üskë̈dar İlcesi Merkez Mahallelerinde Bulunan Osmanl Dönemine Ait Çeşmeler Ve Koruma Durumlar. İstanbul: Yıldız Teknik Üniversitesi Fen Bilimleri Enstitüsü Yüksek Lisans Tezi.

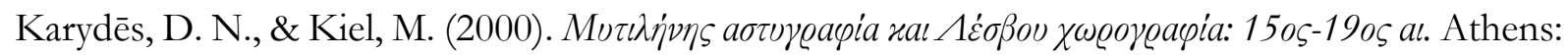
Olkos.

Keil, M. (2005). Midilli. İslâm Anslikopedisi, C. 30, 11-14.

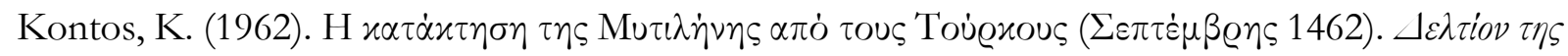

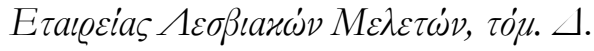

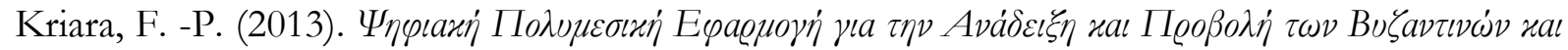

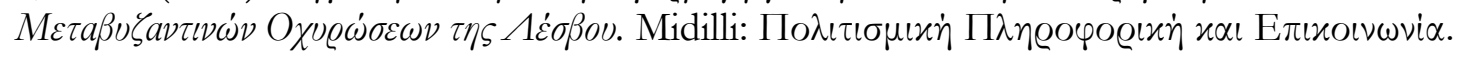

Nicolle, D., \& Hook, A. (2013). Crusader Casteles in Cyprus, Greece and the Aegan 1191-1571. London: Bloomsbury Publishing.

NSSG. (2009). Population \& Housing Census 2001. Athens: Pireas. (NSSG: National Statistical Service of Greece)

Olgun, İ., Altıner, D., Çılgın, K., \& Turgut, E. (2018). Ayvalık ve Lesbos Kırsal Yerleşme Morfolojilerinin Karşılaştırılması. Türkiye Kentsel Morfoloji Arasstırma A ̈̆g II. Kentsel Morfoloji

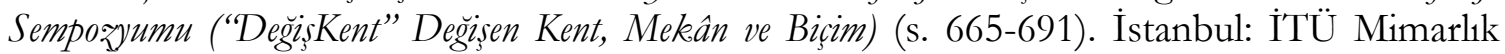
Fakültesi.

Ödekan, A. (1992). Kentiçi Çeşme Tasarımında Tipolojik Çözümleme. Semavi Eyice Armağanı (s. 281-286). içinde İstanbul.

Önge, Y. (1984). V akırf Müessesesinde Su ve Önemi. Ankara: Vakıflar Genel Müdürülüğü.

Önge, Y. (1997). Anadolu Beylikler Döneminin Çeşme, Sebil ve Şadırvanları. Uluslararası Osmanl Öncesi Türk Kültürü Kongresi (1989) Bildirileri (s. 199-214). Ankara: Türk Tarih Kurumu.

Pilehvarian, N. (2002). Osmanlı Çeşme Mimarisi. Türkler Ansiklopedisi (s. 247-251). içinde Ankara: 
Yeni Türkiye Yayınları,

Rebaudo, L. (2016). Un Pellegrinaggio Atıpico. Archeologia E Topografia Nel Viaggio Del Levante Di Bernardo Michelozzi E Bonsignore Bonsignori (1497-1498). Nuova Rivista Storica, 100(2), 639-660.

Ünal, A. A. (2002). XVI.ve XVII.Yüzylllarda Cezayir-i Bahr-i Sefid (Akdeniz, Ege Adalar1) ya da Kapdan Paşa Eyaleti. Erciyes Üniversitesi Sosyal Bilimler Enstitüsü Dergisi(S. 1), 251-261.

\section{YAZARIN BIYYOGRAFİSİ (BIOGRAPHY OF THE AUTHOR)}

\section{Ammar İBRAHİMgİL, Arş. Gör. Dr.}

Gazi Üniversitesi Mimarlık Bölümünden mezun olmuştur. Aynı üniversitede Restorasyon Bilim Dalında yüksek lisans ve doktorasını tamamlamıştır. İki yıl ABB KUDEM'de restoratör mimar olarak görev yaptıktan sonra altı yıl Gazi Üniversitesi’nde araştırma görevlisi olarak çalışmıştır. 2018 yılından itibren de Necmettin Erbakan Üniversitesi Mimarlık Bölümü’nde çalışmaktadır. Çeşitli bilimsel araştırma projelerinde Balkan ülkelerindeki Osmanlı eserlerinin tespiti ve tanımlama çalışmalarına katılmıştır. Rodos Adası'nda Osmanlı Mirası adlı bir kitabı bulunmaktadır. 